FOLIA PRAEHISTORICA POSNANIENSIA T. XXIII - 2018

INSTYTUT ARCHEOLOGII, UAM POZNAŃ - ISSN 0239-8524

http://dx.doi.org/10.14746/fpp.2018.23.06

\title{
KREATYWNOŚĆ ZA DRUTEM KOLCZASTYM: \\ ARCHEOLOGIA I SZTUKA OKOPOWA Z PIERWSZOWOJENNEGO OBOZU JENIECKIEGO W CZERSKU (WOJ. POMORSKIE)
}

\author{
CREATIVITY BEHIND BARBED WIRE: ARCHAEOLOGY \\ AND TRENCH ART FROM A PRISONER OF WAR CAMP \\ IN CZERSK (POMERANIAN PROVINCE)
}

\author{
Dawid Kobiatka \\ Instytut Archeologii i Etnologii Polskiej Akademii Nauk \\ Al. Solidarności 105, 00-140 Warszawa, Polska \\ dawidkobialka@wp.pl
}

\begin{abstract}
This article discusses the results of archaeological and anthropological research concerning material remains of a prisoner of war camp in Czersk (Pomeranian province, Poland) (Kriegsgefangenenlager Czersk). In the first part, I sketch a broader historical context related to building and functioning of the camp in forests around Czersk between 1914-1919. After that, the role and meaning of archaeological research on such type of archaeological sites are presented. In the third part, I focus on a very special category of the camp heritage which is called trench art. The last part of this paper is a case study where an assemblage of objects classified as trench art that was found at the camp is described and interpreted. This text aims at highlighting the value of such prisoners and camp's heritage. Such material culture is a material memory of extraordinary prisoners' creativity behind barbed wire. It makes one aware of how every piece of trash, rubbish was re-cycled during day-to-day life behind barbed wire.
\end{abstract}

KEY WORDS: the Great War, prisoner of war camp, Czersk, trench art, archaeology

\section{OBÓZ JENIECKI W CZERSKU Z CZASÓW I WOJNY ŚWIATOWEJ}

Powstanie obozu jenieckiego w Czersku, wówczas w Prusach Zachodnich (niem. Westpreußen), aktualnie zaś w gminie Chojnice (woj. pomorskie), było bezpośrednią konsekwencją działań na froncie wschodnim związanych z wybuchem 
I wojny światowej. W wyniku zwycięstw wojsk Cesarstwa Niemieckiego dowodzonych przez generałów Paula von Hindenburga i Ericha Ludendorffa pod Tannenbergiem i Wielkimi Jeziorami Mazurskimi do niewoli trafiło już w pierwszych tygodniach walk dziesiątki tysięcy carskich jeńców (Dąbrowski, 2015, s. 150).

Jednym z obiektów założonych przez Niemców do przetrzymywania pojmanych Rosjan w Prusach Zachodnich był obóz w Tucholi (niem. Kriegsgefangenenlager Tuchel) - dzisiejsza gmina Tuchola (woj. kujawsko-pomorskie). Jak wynika ze studiów Zbigniewa Karpusa i Waldemara Rezmera, obóz w Tucholi, jak planowano, miał pomieścić jednorazowo do 20 tysięcy żołnierzy (Karpus, Rezmer, 1997, s. 16). Było to potężne założenie składające się z baraków budowanych z blachy falistej oraz ziemianek, łaźni, kuchni, stajni, magazynów, stref kwarantanny, kantyny itd. (por. Kobiałka, Kostyrko, Kajda, 2016). W ciągu kolejnych tygodni działań wojennych powstawały następne ośrodki mające na celu odizolowanie żołnierzy Ententy. Na tyłach frontu wschodniego w ramach XVII Korpusu Armijnego utworzono ostatecznie jeszcze kilka obozów jenieckich (por. Pope-Hennessy, 1920). Wśród nich były m.in. obiekty w Czersku (niem. Kriegsgefangenenlager Czersk), Czarnem (niem. Kriegsgefangenelager Hammerstein), Bytowie (niem. Kriegsgefangenelager Bütow), Gdańsku-Przeróbce (niem. Kriegsgefangenelager Danzig Troyl).

W tych obozach jenieckiego życia doświadczyły dziesiątki tysięcy ludzi. Największą ich liczbę stanowili żołnierze Armii Imperium Rosyjskiego. Akty zgonów znajdujące się w Archiwum Państwowym w Bydgoszczy potwierdzają też to, że zarówno w Czersku, jak i Tucholi przetrzymywano jeńców brytyjskich, francuskich, włoskich czy też rumuńskich. Można generalne stwierdzić, że tematyka jeńców wojennych i miejsc ich przetrzymywania jest nadal w niewielkim stopniu rozpoznana (por. Westerhoff, 2014; Bączyk, 2015). Tym bardziej należy w tym miejscu wspomnieć o obozie w Tucholi, który doczekał się monograficznego, trzytomowego opracowania (Karpus, Rezmer, 1997, 1998; Karpus, Wiszka, Sribniak, 2008). Również historia obozu w Pile (niem. Kriegsgefangenelager Schneidemühl) została niedawno opisana (Usurski, 2018). Co więcej, wspomnienia dwóch Brytyjczyków, Australijczyka, Rosjanina i trzech Francuzów osadzonych w Pile udało się przetłumaczyć na język polski i wydać drukiem (Bączyk, Kaczmarek, Usurski, 2018).

Podpisanie rozejmu przez Niemcy 11 listopada 1918 r. miało daleko idące konsekwencje dla wszystkich uczestników konfliktu. Jedną z nich było rozpoczęcie zwalniania przetrzymywanych żołnierzy Ententy z obozów jenieckich. Działania te miały miejsce jeszcze w 1919 r. Podobnie było z jeńcami z Czerska i samym obozem. Część infrastruktury obozowej rozebrano, resztę zrównano z ziemią; niektóre obiekty zostały wykorzystane przez lokalną społeczność (por. Kobiałka, Kostyrko, Kajda, 2017a, 2017b). Po dwóch dekadach od zakończenia I wojny światowej krajobraz obozowy był już nie do poznania. Jak pisał w 1939 r. ksiądz Franciszek Smagliński (1993, s. 1): „Co to za ustronie? To miejsce wiecznego spoczynku tysięcy ofiar wojny światowej. To cmentarz rosyjski, jedyna dziś pozostałość po olbrzymim obozie jeńców w Czersku" (por. Bystryk, 2016). 
Utarło się przekonanie, że po obozie pozostało bardzo niewiele materiałów. Na te nieliczne źródła składają się niemieckie pocztówki propagandowe (ryc. 1-2), zdjęcia wykonane na terenie obozu (ryc. 3), szkice prezentujące jeńców, dokumenty znajdujące się w archiwach (np. Archiwum Państwowe w Bydgoszczy, archiwum Muzeum Historyczno-Etnograficznego im. Juliana Rydzkowskiego w Chojnicach).

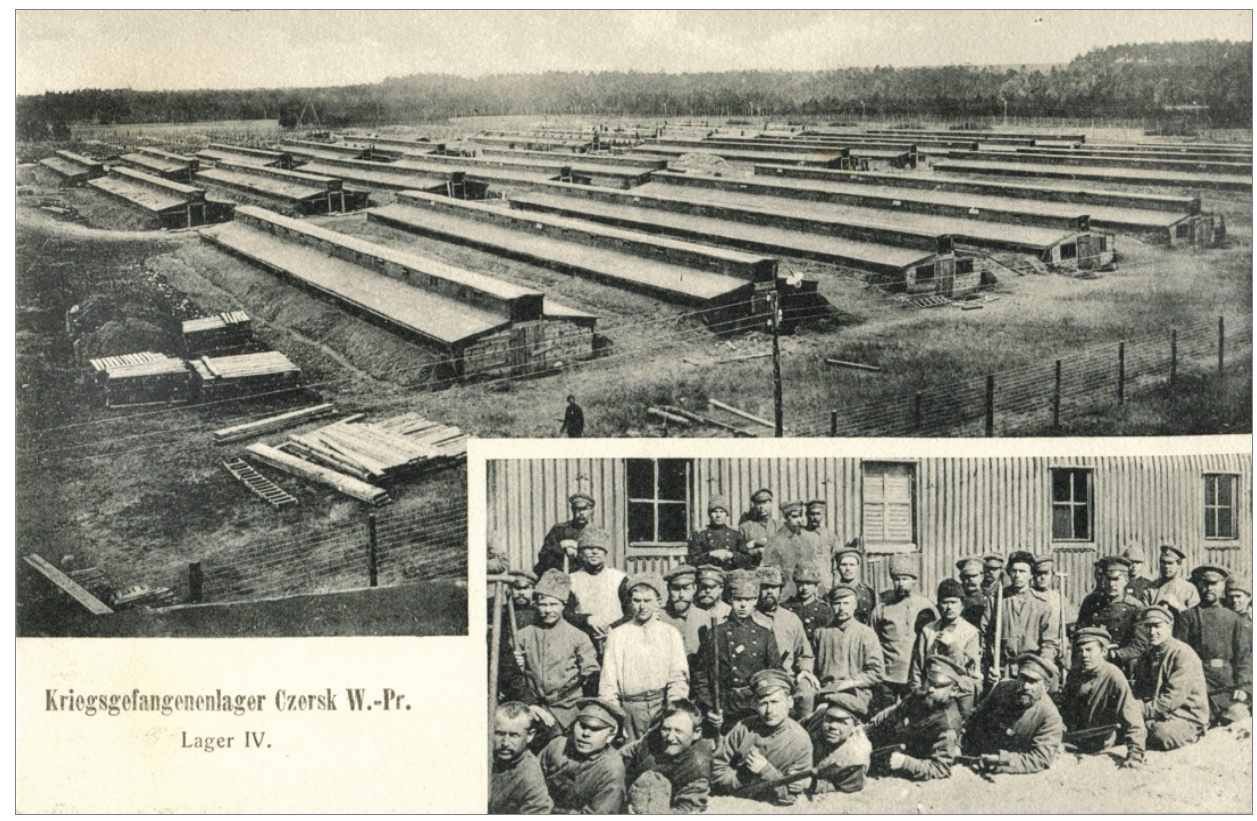

Ryc. 1. Niemiecka pocztówka propagandowa przedstawiająca obóz w Czersku (zbiory prywatne Dawida Kobiałki).

Fig. 1. A German propaganda postcard presenting the prisoner of war camp in Czersk (private collection's Dawid Kobiałka).

Tak jak pisał ksiądz Smagliński, to cmentarz jeniecki ma być najbardziej oczywistym, wymownym świadectwem, że w lasach pod Czerskiem istniał potężnych rozmiarów obóz jeniecki (ryc. 4). Wcześniejsze ustalenia sugerowały, że na cmentarzu miało spocząć 8505 jeńców (Karpus, Rezmer 1997, s. 19). Ostatnie studia mówią o liczbie 5116 żołnierzy, która nigdy nie opuściła obozu w Czersku (Wąsiewski, 2017, s. 26).

Celem wstępnych, nieinwazyjnych badań archeologicznych na terenie obozu w Czersku, które prowadzone są od 2014 r., było oszacowanie stanu zachowania reliktów obozowych. Okazało się, że cmentarz nie jest jedyną dzisiaj pozostałością po obozie jeńców w Czersku (więcej w Kobiałka, Kostyrko, Kajda, 2017a, 2017b). W lokalnym krajobrazie zachowały się subtelne zmiany (zagłębienia) będące śladami 

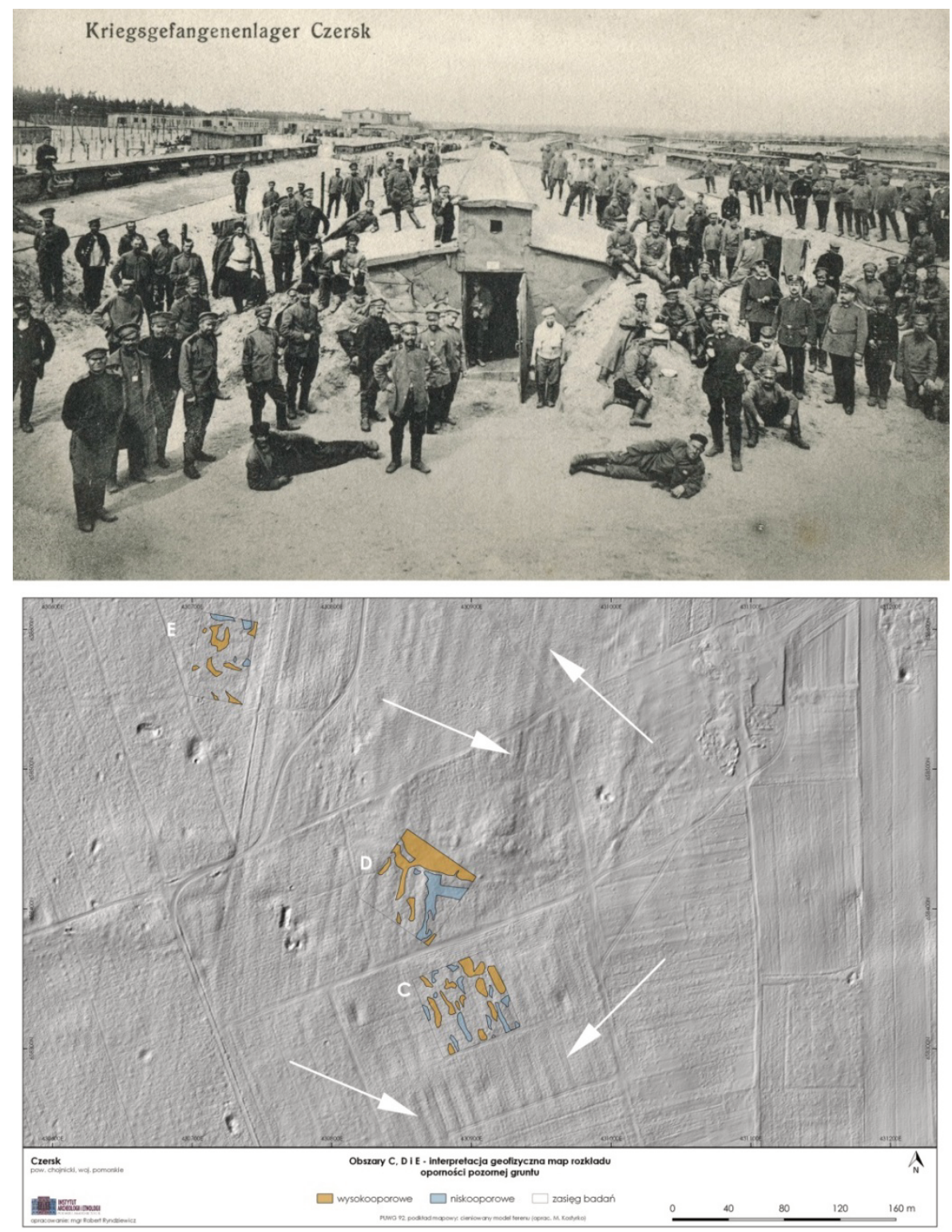

Ryc. 2. Różne wymiary pozostałości po obozie jenieckim w Czersku. Góra - niemiecka pocztówka propagandowa przedstawiająca obóz w Czersku (zbiory prywatne Dawida Kobiałki). Dół - interpretacja geofizyczna map rozkładu oporności pozornej gruntu dla wybranych fragmentów obozu w Czersku nałożona na cieniowany model terenu; białe wskaźniki wskazują przykładowe obiekty obozowe (oprac. Robert Ryndziewicz).

Fig. 2. Various categories of remains of a PoW camp in Czersk. Top - a German propaganda postcard presenting the prisoner of war camp in Czersk (private collection's Dawid Kobiałka). Bottom - interpretation of geophysical survey of the selected parts of the Czersk camp on hillshade visualization; white arrows indicate some of the camp's remains (prep. by Robert Ryndziewicz). 

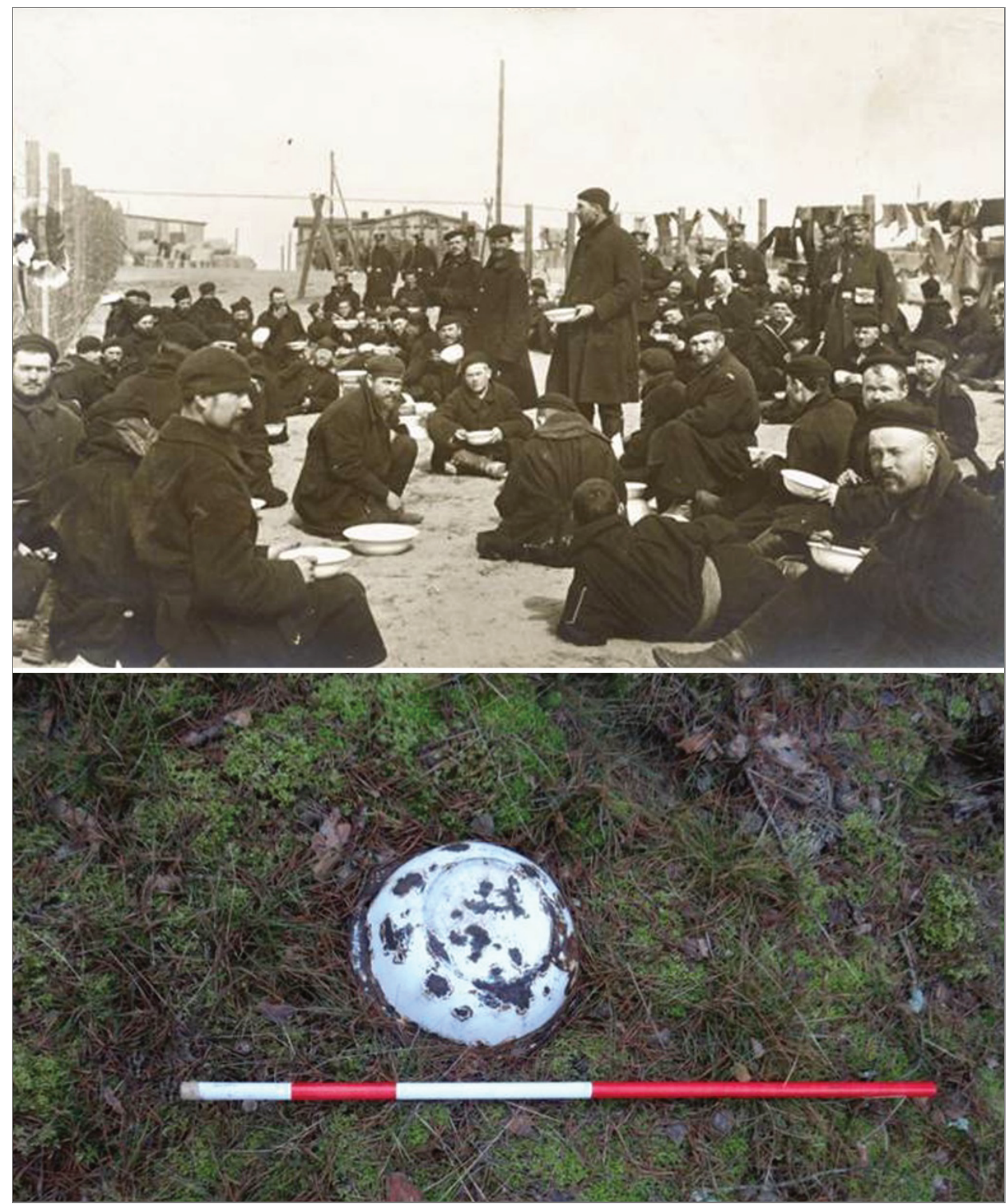

Ryc. 3. Historia i archeologia obozu w Czersku. Góra - zdjęcie archiwalne ukazujące grupę jeńców w Czersku w trakcie najprawdopodobniej spożywania posiłku z charakterystycznych białych emaliowanych mis (zbiory prywatne Dawida Kobiałki). Dół - jedna z mis zadokumentowanych w trakcie badań terenowych (fot. Dawid Kobiałka).

Fig. 3. History and archaeology of the Czersk camp. Top - an archive photography presenting a group of prisoners of war at the Czerk camp during a meal in characteristic, white, enameled bowls (private collection's Dawid Kobiałka). Bottom - one of the bowls documented during the field research (photo by Dawid Kobiałka). 


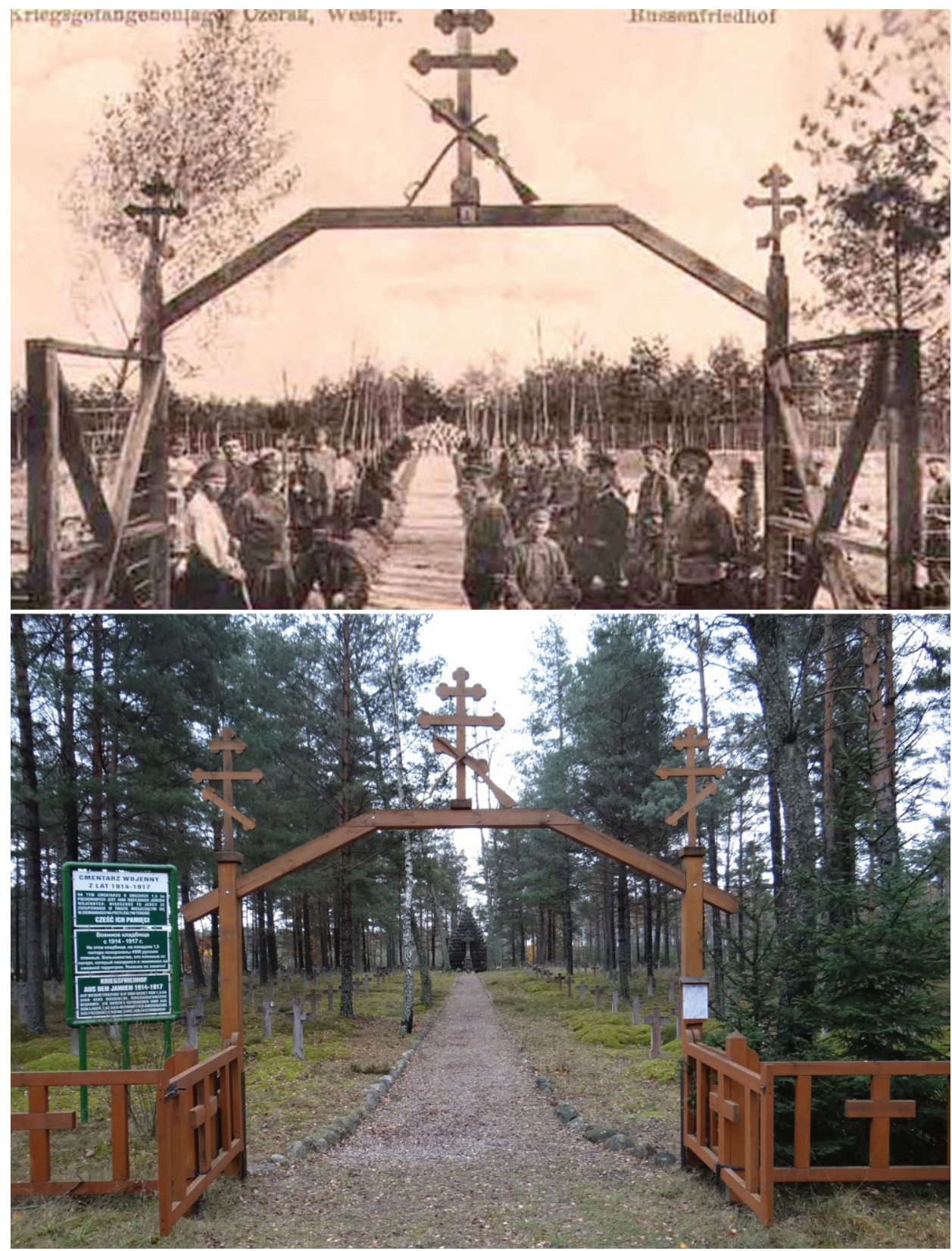

Ryc. 4. Cmentarz jeńców pierwszowojennych w Czersku. Góra - cmentarz w trakcie jego funkcjonowania w trakcie Wielkiej Wojny (zbiory prywatne Dawida Kobiałki). Dół - rekonstrukcja bramy cmentarnej, stan na 2017 r. (fot. Dawid Kobiałka).

Fig. 4. A prisoner of war cemetery in Czersk. Top - a cemetery during its functioning between 1914 1919 (private collection's Dawid Kobiałka). Bottom - a contemporary reconstruction of the cemetery gate in 2017 (photo by Dawid Kobiałka). 
po miejscach, w których stały obiekty obozowe (baraki, ziemianki, magazyny, stacja transformatorowa, jamy śmietnikowe, plac apelowy itd.). Obóz jeniecki to również specyficzna kultura materialna, która związana była $\mathrm{z}$ codziennym jego funkcjonowaniem. Nie jest zatem tak, jak sądzono, że po obozie prawie nic nie pozostało do współczesności. Jest wręcz odwrotnie. Zasadniczy problem, który uwidocznił się już na etapie prowadzenia rekonesansu terenowego (badania powierzchniowe, badania geofizyczne, zdjęcie lotnicze), jest taki, że w lasach okalających Czersk pozostała ogromna wręcz ilość materii (kultury materialnej i materialnych przekształceń krajobrazowych) związanej z istnieniem miejsca odosobnienia żołnierzy Ententy.

Zamierzeniem niniejszego artykułu jest zwrócenie uwagi i omówienie specyficznej kategorii jenieckiej kultury materialnej, którą w literaturze przedmiotu określa się mianem sztuki okopowej (ang. trench art). Stanowi ona przejaw jenieckiej kreatywności za drutem kolczastym. Tłem wywodu będą wyniki studiów archeologiczno-antropologicznych dotyczących materialnych pozostałości po pierwszowojennym obozie jenieckim w Czersku. Zasygnalizuję potencjał archeologii w kontekście badań dotyczących materialnych pozostałości po jeńcach wojennych i obozach jenieckich. Kolejna część pracy poświęcona jest opisowi, czym sztuka okopowa jest oraz jej podziałowi typologicznemu (za: Saunders, 2010). Ostatni rozdział tekstu to studium przypadku kilku przykładów sztuki okopowej związanej z obozem w Czersku.

\section{ARCHEOLOGIA I JEŃCY WOJENNI: KRÓTKI ZARYS PROBLEMATYKI}

Warto wyraźnie podkreślić, że studia nad kulturą materialną czasów najnowszych są bardzo dynamicznie rozwijającą się gałęzią dociekań archeologicznych. Dzisiaj jest to różnorodne pole badań terenowych i refleksji teoretycznej. Taką naukę określa się w literaturze jako m.in. archeologie wspótczesnej przeszłości (ang. archaeologies of the contemporary past) (Buchli, Lucas, 2001). W jej ramach dominującą pozycję zajęły studia poświęcone różnym materialnym aspektom współczesnych konfliktów zbrojnych (ang. modern conflict archaeology) (por. Saunders, 2010). W tym kontekście należy umieszczać m.in. badania archeologiczne na terenach byłych obozów jenieckich. Na przestrzeni ostatnich lat ukazały się trzy ważne opracowania podsumowujące rolę i znaczenie archeologii w badaniu tego rodzaju przestrzeni (Myers, Moshenska, 2011; Carr, Mytum, 2012a; Mytum, Carr, 2013a).

Działania archeologiczne na terenach obozów jenieckich nie są stricte analizami historycznymi (por. Cesarani, Kushner, 1993; Cresswell, 2005; Nagornaja, Mankoff, 2009). To znaczy, że archeolodzy świadomie stosują bardziej materialną optykę badań niż historycy. Mówiąc jaśniej, archeologom chodzi o odsłanianie/przywracanie wspomnień rzeczy (ang. thing memories): co można powiedzieć o danym obozie, jeńcach, zaopatrzeniu, życiu obozowym jako takim przez przedmioty związane z konkretnym miejscem (por. Olivier, 2011; Olsen, Witmore, 2014). Innymi słowy 
archeologiczne badanie obozów nie sprowadza się jedynie do analizowania wspomnień, dokumentów pisanych, historii mówionych.

Obozy były zwykle potężnymi założeniami architektonicznymi. Rozpościerały się one na powierzchni dziesiątek hektarów. Obóz w Tucholi liczył - jak się szacuje (Karpus, Rezmer, 1997) - niespełna 70 hektarów, na których budowane były kolejne obiekty obozowe. Obóz w Czersku był jeszcze większy (Kostyrko, 2018). Wraz z zakończeniem I wojny światowej w większości przypadków budynki obozowe były demontowane, przenoszone czy też zrównywane z ziemią. Drewno z baraków wykorzystywano jako opał na potrzeby lokalnej społeczności (Usurski, 2018). W sporej ilości przypadków pokutują wyobrażenia, że niemalże nic z pierwszowojennych obozów jenieckich nie przetrwało do czasów współczesnych. Również sami jeńcy już dawno nie żyją, jak to jest w przypadku I wojny światowej. Za dwie dekady nie będzie żywych świadków II wojny światowej. Niedawna przeszłość przechodzi z zakresu obszaru żywej pamięci $\mathrm{w}$ etap postpamięci, z pola historii $\mathrm{w}$ obszar archeologii. Jak twierdzą Garbiel Moshenska i Adrian Myers (2011), nowy, alternatywny wgląd w życie obozowe, w strategie przetrwania, relacje społeczne, codzienne życie za drutem kolczastym itd. będzie można uzyskać przede wszystkim przez analizę obozowej kultury materialnej.

Stopniowe zainteresowanie problematyką jeniecką/obozową powoduje zasadność dookreślenia specyfiki tego rodzaju badań archeologicznych (Myers, Moshenska, 2014; Mytum, 2014). Jest ona odmiennie określana przez różnych badaczy. Na przykład Moshenska i Myers (2011) postulowali, aby tego rodzaju studia objąć terminem archeologii internowania (ang. archaeologies of internment). W innym ważnym opracowaniu Harold Mytum i Gilly Carr (2013a) pisali o archeologii jenieckiej (ang. prisoner of war archaeology, the archaeology of prisoners of war) jako pojęciu adekwatnie oddającym wielość i złożoność podejść w ramach odkrywania, analizowania materialnych pozostałości po jeńcach i miejscach ich przetrzymywania. Istnieją także węższe pojęcia stosowane w kontekście dziedzictwa drugowojennego, jak np. archeologia eksterminacji (ang. archaeology of extermination; Gilead, Haimi, Mazurek, 2010) czy też archeologie Holocaustu (ang. Holocaust archaeologies; Sturdy Colls, 2015). Mimo pewnych różnic w konceptualizacji i rozumieniu wkładu archeologii, wszystkie te przykłady potwierdzają, że archeologia może być istotnym podejściem w badaniu dziedzictwa jenieckiego i obozowego.

Taka archeologia oferuje ramy interpretacyjne do badania życia codziennego za drutem kolczastym. Zarazem jest ona podejściem, które uwzględnia refleksję nad współczesną rolą i znaczeniem reliktów obozowych. Tego rodzaju materialne pozostałości, także dzięki badaniom archeologicznym, coraz częściej są postrzegane, badane i prawnie chronione jako wartościowe dziedzictwo o wymiarze kulturowym i historycznym. $Z$ perspektywy archeologii należy dodać, że przedmioty obozowe są zarazem dziedzictwem archeologicznym. Jak zauważają Mytum i Carr (2013b, s. 15; thum. autora): 
Archeologia jeniecka jest ekscytującym, innowacyjnym i poruszającym medium, przez które trudne aspekty relatywnie niedawnej przeszłości mogą być eksplorowane, interpretowane i którym można stawić czoło. Odsłania ona często zapomniany aspekt czasów wojennych danych państw, lecz oferuje więcej niż eklektyczne odejście od dominującej archeologii.

Również drugowojenne obozy niemieckie, które znajdują się w granicach współczesnej Polski, były obiektem zainteresowania archeologów. Niedawne prace na terenach takich obozów, jak w Bełżcu (Kola, 2000), Sobiborze (Gilead, Haimi, Mazurek, 2010), Auschwitz-Birkenau (Majorek, Gruppa, 2015), Chełmie nad Nerem (Pawlicka-Nowak, 2015) czy też ostatnio KL Plaszow (Karski, Różycki, Schwarz, 2017) przyniosły interesujące wyniki oraz autentyczne, oryginalne przedmioty związane $\mathrm{z}$ danym miejscem. W każdym przypadku archeologom udało się pozyskać nieznany wcześniej zbiór informacji dotyczący życia obozowego, sposobów ich organizacji czy też technik tuszowania śladów zbrodni. W tym kontekście może dziwić to, że obozy pierwszowojenne były poza bliższym zainteresowaniem archeologów. Dopiero na przestrzeni ostatnich lat podjęto w Polsce pierwsze tego rodzaju rozpoznanie archeologiczne (Rola, Stasiak, Kwiatkowska, 2015; Kobiałka, Kostyrko, Kajda, 2016, 2017a, 2017b). Niniejszy tekst stanowi kolejny głos w tej dyskusji.

Wyżej zarysowane rozumienie archeologii było ramą interpretacyjną do podjęcia studiów nad materialnymi reliktami po pierwszowojennym obozie jenieckim w Czersku. Były one częścią realizacji projektu badawczego pt. Między pamięcia a zapomnieniem: archeologia a XX-wieczne dziedzictwo militarne na terenach zalesionych (por. archeolasy.pl). W jego ramach najważniejszym elementem przyjętej metodyki badawczej była analiza pochodnych lotniczego skanowania laserowego, która pozwoliła częściowo odtworzyć przestrzenne rozplanowanie obozu (por. Kobiałka, Kostyrko, Kajda, 2017a, 2017b) (ryc. 5). Pozyskane chmury punktów były rezultatami realizacji Informatycznego Systemu Osłony Kraju przed nadzwyczajnymi zagrożeniami (ISOK; por. Wężyk, 2014). Mimo tego, że pomiary nie były dokonywane w celach archeologicznych, to dane zebrane w ramach ISOK-u okazały się wartościowym materiałem do archeologicznych analiz krajobrazowych (Wroniecki, Jaworski, Kostyrko, 2015).

Kolejnym etapem postępowania badawczego były rekonesanse terenowe, podczas których dokumentowano przedmioty po jeńcach, takie jak: zardzewiałe miski, kubki, strzępy papy, gwoździe, fragmenty piecyków żeliwnych, butelki szklane itd. Poszukiwania archiwalne oryginalnych dokumentów z epoki oraz kwerendy muzealne były także częścią projektu. Z kolei w 2018 r. przeprowadzono badania geofizyczne (metoda elektrooporowa) oraz zdjęcia lotnicze terenu byłego obozu. W końcu elementem badań terenowych było zbieranie i spisywanie wspomnień związanych z obozem i jeńcami, które przetrwały wśród mieszkańców Czerska i okolic. Właśnie w wyniku takich poszukiwań archeologiczno-antropologicznych dotarłem do niewielkiej izby pamięci w Czarnej Wodzie, w której regionalista Piotr Szulc legalnie 

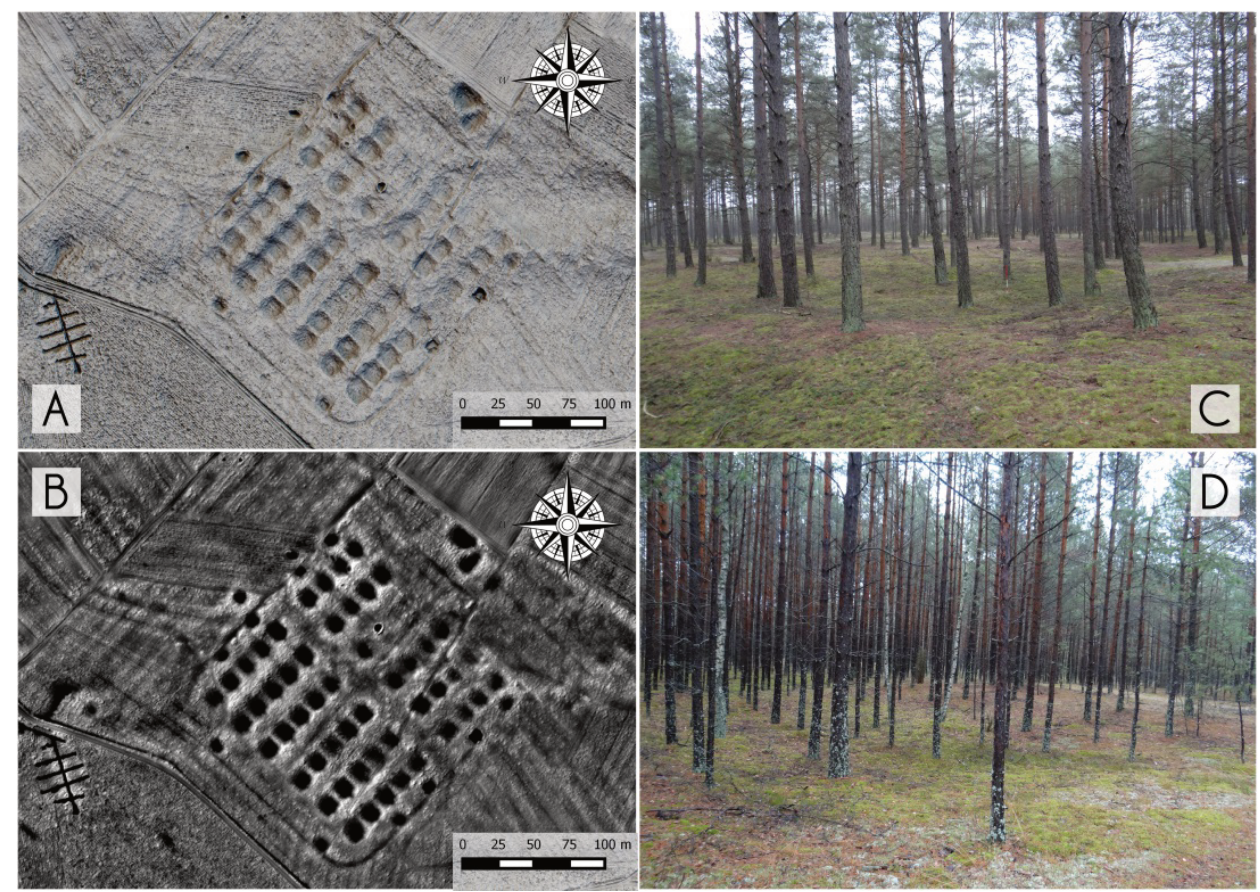

Ryc. 5. Ziemianki obozowe z Czerska. A-B - dokumentacja obiektów na pochodnych lotniczego skanowania laserowego; C-D - pozostałości ziemianek w lokalnym leśnym krajobrazie (oprac. M. Kostyrko, fot. Dawid Kobiałka).

Fig. 5. Camp's dug-outs. A-B - structures documented on LiDAR-derivatives; C-D - remains of dug-outs in the local woodlands (prepared by M. Kostyrko, photo by Dawid Kobiałka).

kolekcjonuje przedmioty związane z jeńcami z Czerska. Część jego zbiorów to rzeczy wykonane, przetworzone przez samych osadzonych. Stanowią one unikatowe przykłady sztuki okopowej z frontu wschodniego.

Problematyka sztuki okopowej nie doczekała się bliższej analizy na łamach polskiej archeologii. $\mathrm{Z}$ tego powodu, zanim przejdę do omówienia konkretnych jenieckich artefaktów, zaprezentuję nieco bliżej zagadnienie sztuki okopowej frontu zachodniego Wielkiej Wojny.

\section{SZTUKA OKOPOWA}

Brytyjski archeolog i antropolog I wojny światowej Nicholas Saunders (np. 2000, 2003, 2004) przez sztukę okopową rozumie każdy przedmiot wykonany ręką żołnierza, jeńca wojennego lub też cywila, który powstał z materiałów wojennych (np. łuski po pociskach artyleryjskich, naboje, hełmy, bagnety itd.) lub też czasowo, 
przestrzennie odnosi się do danego konfliktu zbrojnego. Są to rzeczy wyjątkowe, często pojedyncze egzemplarze przedmiotów pozwalające analizować - jak twierdzi Saunders - totalność doświadczenia konfliktu: ludzkie lęki, troski, myśli, doświadczenia, uczucia, wspomnienia utrwalone w i poprzez materię. Jest ona łącznikiem między żywymi a martwymi; często niedyskursywnym upamiętnieniem doświadczenia wojennego w jego różnorodności, złożoności oraz fragmentaryczności. Stąd też Saunders stosuje wymowny termin object-memory (przedmiot pamięci), podkreślając tym samym, że sztuka okopowa to specyficzne połączenie materii i pamięci w czasach konfliktu zbrojnego i o danej wojnie.

Zaproponowane przez Saundersa rozumienie sztuki okopowej jest bardzo szerokie i ogólne. Taką jednak ma ona w rzeczywistości naturę. To znaczy sztuka okopowa to przedmioty wykonywane zarówno w metalu, jak i w drewnie, na papierze, tekstyliach, liściach dębowych itd. To zarazem rzeczy, które łączyły materiały różnego rodzaju. Czyli - co należy jasno podkreślić - sztuka okopowa nie odnosi się w dosłownym znaczeniu do dzieł sztuki, które zostały zrobione lub też odnalezione w okopach. Jest to pojęcie bardziej wieloznacznie i szerokie. W jego ramach mieszczą się także artefakty wykonane, przerobione przez żołnierzy w obozach jenieckich. W literaturze spotyka się czasem osobne określenie na tego typu kulturę materialną: sztuka obozowa (ang. camp art) (por. http://www.auschwitz.org...). Niemniej według rozumowania brytyjskiego archeologa, o czym więcej poniżej, sztuka wykonywana w obozach to nadal przykłady sztuki okopowej. Tak definiowanym konceptem posługuję się w dalszej części wywodu.

Przedmioty stworzone przez żołnierzy, jeńców wojennych, ludność cywilną w celu upamiętnienia danego konfliktu zbrojnego nie są fenomenem, który narodził się wraz z wybuchem Wielkiej Wojny. W swoim już klasycznym studium Saunders (2003) analizuje artefakty zarówno z XIX wieku, jak i z czasów wojny w Wietnamie czy nawet niedawnego konfliktu na Bałkanach. Warto nadmienić, że sztuka okopowa nie dotyczy przeszłych konfliktów zbrojnych. Nie jest to minione zjawisko kulturowe. Można zaryzykować twierdzenie, że wytwarzanie i przerabianie kultury materialnej towarzyszącej wojnom jest elementem każdych działań militarnych. Ostatni konflikt zbrojny w Syrii jest tego niestety sugestywnym potwierdzeniem. Dla przykładu, miejscowy syryjski artysta Akram Abo Alfoz wykorzystuje niewybuchy, łuski po pociskach, żołnierskie hełmy itd. jako surowiec do tworzenia dzieł sztuki (ryc. 6). Przetwarza on obiekty mające nieść śmierć w artefakty o wartości estetycznej i niosące nadzieję na przyszłość. W pewien sposób udomawia on śmierć. Jak głosi tytuł materiału filmowego dokumentującego działalność Abo Alfoza, jego instalacje to malowanie na śmierci (ang. Painting on Death) (por. https://religion research.org/closer/2016/12/30...). Próbuje on przekuć, a mówiąc dosłownie, przemalować śmierć na nadzieję. Tak artysta mówił o idei przyświecającej przetwarzaniu śmiercionośnych artefaktów: „,Te dzieła sztuki - dopisek D.K.] służą jako wia- 
domość nadziei, wytrwałości i walki zarazem. Są także przypomnieniem dla tych, którzy mogą nas zobaczyć, a jednak zachowują milczenie (Abo Alfoz, 2017; tłum. autora) (por. https://religionresearch.org/closer/2016/12/30...). Chociaż syryjski artysta używa terminu dzieło sztuki (ang. artwork) na określenie swojej działalności, to $\mathrm{z}$ archeologicznego punktu widzenia jego prace to nic więcej jak właśnie przykłady sztuki okopowej.

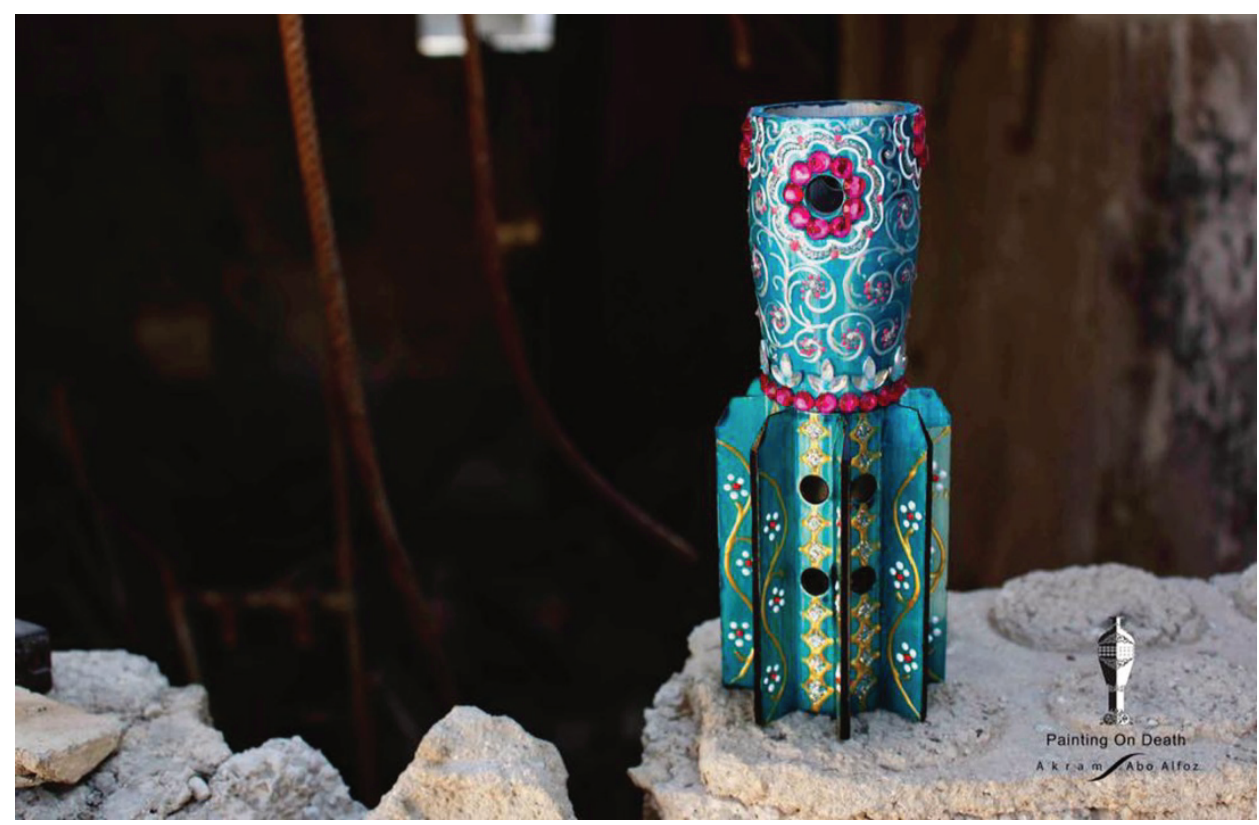

Ryc. 6. Malowanie na śmierci - współczesny przykład sztuki okopowej z terenu konfliktu w Syrii (fot. A. Abo Alfoz).

Fig. 6. Painting on Death - an example of contemporary trench art from terrain of the conflict in Syria (photo by A. Abo Alfoz).

Należy jednak podkreślić, że to czas Wielkiej Wojny i lata 20., 30. XX wieku były okresem, kiedy sztuka okopowa przeobraziła się w proces o znaczeniu społecznym, kulturowym, a nawet ekonomicznym. Obserwacja ta dotyczy przede wszystkim sytuacji w Belgii, Francji i na Wyspach Brytyjskich. O różnorodności i wielości form materialnego upamiętniania wydarzeń, doświadczeń, osobistych losów żołnierzy stojących w okopach na froncie zachodnim doskonale zaświadcza porównanie, według którego pierwsza światowa apokalipsa była także wojną na pamiątki, konfliktem pamiątek (ang. a war of souvenirs) (Saunders, 2010, s. 35), wojną na różne formy jej osobistego oraz społecznego upamiętnienia. 
Już w 2000 r. Saunders (2000) w swoim ważnym artykule pt. Bodies of Metal, Shells of Memory: 'Trench Art', and the Great War Re-cycled postulował systematyzację wielkowojennej sztuki okopowej na trzy kategorie. W późniejszych latach była ona rozbudowywana i uszczegóławiana. W Killing Time. Archaeology and the First World War Saunders (2010) zaproponował następujący podział, który warto omówić nieco bliżej. Kluczem klasyfikacyjnym nie był jednak kształt, waga, funkcja, materiały, z których powstały dane przykłady sztuki okopowej (por. Minta-Tworzowska, 1994). Poszczególne kategorie zostały oparte na ustaleniu, kto i kiedy zrobił dany artefakt. Poniższa typologia ma charakter analityczny - sam brytyjski archeolog był doskonale świadomy, że niektóre artefakty mogą, przez swoją złożoność i ambiwalencję, być elementem różnych zbiorów (kategorii). Nierzadko także brakuje bliższych informacji, które pozwoliłby zakwalifikować dany przedmiot do właściwego zbioru.

Kategoria 1 obejmuje artefakty wytworzone przez żołnierzy biorących, w takim czy innym wymiarze, udział w walkach. Przykłady sztuki okopowej tej kategorii powstawały mniej więcej od 1914 do 1930 r. Stanowią one zarazem najmniejszy zbiór, jeśli chodzi o liczbę rzeczy, przykładów sztuki okopowej z frontu zachodniego. Niemniej jest to zespół bardzo różnorodny, w skład którego wchodzą np.: pierścionki wykonywane $\mathrm{z}$ aluminium czy też z mosiądzu, zapalniczki z nabojów, kubki robione $\mathrm{z}$ dolnych części łusek od pocisków artyleryjskich czy też noże do listów, które były konstruowane z różnego rodzaju metalowych odpadów. Tutaj Saunders wydziela cztery dodatkowe subkategorie.

Subkategoria 1a to artefakty robione przez żołnierzy w trakcie trwania konfliktu (1914-1918). Subkategoria 1b obejmuje rzeczy wykonane, przetworzone przez żołnierzy wziętych do niewoli i przetrzymywanych w obozach jenieckich. Ich datowanie wypada na lata 1914-1919. Sztuka z obozów ma inny charakter. Zwykle była wykonywana dla zabicia czasu, w celu wymiany przedmiotów na pożywienie, papierosy itd. czy też jako rzeczy ułatwiające przetrwanie pobytu za drutem kolczastym. Nie ma zatem w tej subkategorii klasycznych wazonów z łusek po pociskach artyleryjskich czy też krucyfiksów z pocisków karabinowych. Wyróżnia się tu więcej przedmiotów z materiałów łatwo dostępnych jeńcom, jak drewno, tekstylia czy kość. Jako przykład Saunders (2010, s. 47) prezentuje ozdobę przedstawiającą węża, która została wykonana z paciorków przez pewnego tureckiego jeńca. Zaznaczam już w tym miejscu, że to właśnie do subkategorii $1 \mathrm{~b}$ należą wszystkie artefakty, przykłady sztuki okopowej z Czerska, które będą analizowane w ostatniej części artykułu. Subkategoria 1c obejmuje przedmioty wykonywane przez rannych żołnierzy oraz rekonwalescentów w trakcie czasu spędzonego w lazaretach, szpitalach czy też ośrodkach, w których wracali do zdrowia. Najbardziej charakterystycznymi artefaktami są tu różnego rodzaju przykłady haftów, robótek ręcznych. W końcu subkategoria $1 \mathrm{~d}$ obejmowałaby przedmioty stworzone przez nowych rekrutów już po za- 
kończeniu działań zbrojnych. To artefakty, których twórcami byli żołnierze okupujący Nadrenię w latach 1918-1930. Były to głównie metalowe plakietki, forma pamiątki z czasu służby w zajmowanym kraju.

Kategoria 2 obejmuje przedmioty z lat 1914-1939. Jest ona najbogatszą grupą kultury materialnej, jeśli chodzi o ilość artefaktów, zarazem znacznie mniej różnorodna niż wcześniejsza kategoria. Były to zwykle rzeczy o charakterze symbolicznym, a nie funkcjonalnym jak w kategorii 1 . Saunders ma tu na myśli kulturę materialną, która powstawała na tyłach walk. W tym zbiorze brytyjski archeolog umieszcza wręcz kanoniczne zdobione wazony wykonywane z łusek do różnego kalibru pociskach artylerii. W jego skład wchodzą zwykle zdobione, pokryte różnej natury grawerunkami noże do listów czy też niewielkie krzyże wykonywane z pocisków do broni palnej. Twórcami tych artefaktów była miejscowa ludność Francji i Belgii, która w zdewastowanych krajach próbowała zarobić na utrzymanie swoich rodzin. Ta sztuka okopowa to kultura materialna wykonywana przez cywilów. Jak zauważa Saunders (2000, s. 51; tłum. autora) w innym miejscu: „sztuka okopowa wykonywana $\mathrm{z}$ metalu szybko rozwinęła się $\mathrm{w}$ chałupnictwo [ang. cottage industry]". Z tego powodu wyodrębniono trzy subkategorie w ramach kategorii 2 . Subkategoria 2a obejmuje głównie przedmioty metalowe, które były sprzedawane żołnierzom obu stron walczących w okopach w Belgii i Francji. Subkategoria $2 b$ obejmuje artefakty, pamiątki kupowane przez wdowy, pielgrzymów oraz turystów odwiedzających pola walki po zakończeniu działań wojennych w 1918 r. Subkategoria 2c to zbiór artefaktów wykonanych przez ludność cywilną, która w trakcie trwania Wielkiej Wojny żyła na terytorium przeciwnika i po wojnie trafiła do specjalnych obozów internowania. Jak pisze Saunders (2010, s. 49; tłum. autora): „Ten przedział sytuacji dał różne znaczenia tym przedmiotom z wojny".

Ostatnia grupa artefaktów, czyli kategoria 3, obejmuje w przybliżeniu rzeczy powstałe między 1918 a 1939 r. To zdaniem brytyjskiego badacza najbardziej zwięzła grupa kultury materialnej, jeśli chodzi o czas, miejsce powstania i samą jej formę. Artefakty robione były z odpadków wojennych, które były przywożone jako surowe, nieobronione pamiątki z kontynentu na Wyspy. Dostawcami byli głównie personel pomocniczy i żołnierze, którzy przeżyli walki na froncie. Dziedzictwo wojenne było skupowane przez prywatne zakłady rzemieślnicze. Jednym z nich był, jak podaje Saunders (2010, s. 54) w swoim tekście, the Army and Navy Store, który oferował tworzenie pamiątek wojennych pod konkretnego klienta, uwzględniając jego upodobania, osobiste doświadczenia wojenne itd. To artefakty, które były często formą, jak zauważa brytyjski archeolog, trofeów myśliwskich eksponowanych w domach w widocznych, honorowych miejscach. Przykłady rzeczy z kategorii 3 to $\mathrm{np}$. zegary wykonywane $\mathrm{z}$ łusek i nabojów, różnego rodzaju lampki i świeczniki czy też pojemniki na atrament tworzone z łusek czy granatów. Wytwarzanie sztuki okopowej stało się przez pewien czas intratnym przemysłem, formą materialnego upa- 
miętniania doświadczeń wojennych na masową wręcz skalę. Można powiedzieć, że skoro I wojna światowa była konfliktem o wymiarze industrialnym, to również jej upamiętnienie przybrało formy i rozmiary wręcz przemysłowe.

Idąc tropem rozumowania brytyjskiego archeologa, można stwierdzić, że sztuka okopowa w całej swej różnorodności i złożoności jest ucieleśnieniem tego, co jednostkowe i tego, co społeczne; materii i idei. To materialne medium między przeszłością a współczesnością, między martwymi, którzy polegli na polu walki a żywymi. Jest manifestacją relacji łączących ludzi i rzeczy w trakcie konfliktu zbrojnego oraz życia w jego cieniu. Jak to trafnie ujął już w 2000 r. Saunders (2000, s. 45; thum. autora):

Przykłady sztuki okopowej są uprzedmiotowieniem ,ja”, symbolizując głęboki smutek, stratę i żałobę [...]; są przejmująco związane z pamięcią i krajobrazem; z zagadnieniami dziedzictwa i wystaw muzealnych, które coraz bardziej podkreślają powszechne doświadczenia żołnierza w trakcie wojny. Są one związane z pielgrzymkami i turystyką szczególnie biorąc pod uwagę ich symboliczny status jako pamiątek [...]. Dodatkowo takie przedmioty są głównym przykładem recyklingu [...]. Słowem sztuka okopowa z metalu jest ucieleśnieniem złożonych relacji między ludźmi i rzeczami, które oni tworzą, użytkują i reużytkują - w fizycznych, duchowych oraz metaforycznych światach przez nich konstruowanych i zamieszkałych.

To właśnie studia Saundersa sprawiły, że sztuka okopowa frontu zachodniego w całym swym bogactwie i różnorodności stała się tematem bliższego zainteresowania archeologicznego i antropologicznego (np. Tomczyszyn, 2004). Niemniej, śledząc literaturę przedmiotu, można zauważyć, że większość badaczy zajmuje się frontem zachodnim Wielkiej Wojny i jej materialnymi pozostałościami. W tych pracach brakuje analizy, studiów porównawczych z warunkami panującymi na froncie wschodnim. Sytuacja jest zrozumiała: sztuka okopowa miała tutaj inną dynamikę, nie prowadzono bliższych studiów archeologicznych pod tym kątem. Na obecną chwilę brakuje nawet materialnych przykładów wschodniofrontowej sztuki okopowej. Stąd też - co oczywiste - brakuje uwzględniania specyfiki sytuacji na froncie wschodnim i jego tyłach.

Dlatego też tak wartościowymi i wyjątkowymi w tym kontekście są pierwsze prace polskich archeologów dotyczące - mówiąc najogólniej - materialnych pozostałości po froncie wschodnim (np. Karczewski, Karczewska, 2014; Czarnowicz, Ochał-Czarnowicz, Kołodziejczyk, 2016; Zalewska, 2016; Zalewska, Cyngot, 2017). Tu też należy lokować wartość artefaktów z Czerska. Jest to zwięzły zbiór przedmiotów pochodzących z jednego miejsca ukazujący wschodniofrontową sztukę okopową w jej jednostkowości i unikatowości. Zatem w ostatniej części pracy analizuję zaledwie kilka artefaktów, które - według podziału Saundersa - można zaliczyć do kategorii 1b sztuki okopowej: przedmiotów wykonanych przez samych żołnierzy (jeńców) między 1914 a 1919 r. 


\section{KREATYWNOŚĆ ZA DRUTEM KOLCZASTYM: SZTUKA OKOPOWA ZWIĄZANA Z OBOZEM W CZERSKU}

Zbiór sztuki okopowej z terenu obozu jenieckiego w Czersku, który znajduje się na Wystawie Przyrody Borów Tucholskich i Doliny Rzeki Wdy w Czarnej Wodzie, obejmuje kilkadziesiąt przedmiotów. Część kolekcji została już bliżej opisana i zinterpretowana (np. Kobiałka, 2017, 2018a, 2018b).

Artefakty wykonane lub też przetworzone przez jeńców z Czerska są bardzo różnorodne. Wśród nich można wyróżnić m.in. numery obozowe, zawieszki, medaliki, kubki, szklanki, łyżki, kociołki, pędzle do golenia, szkatułki, grawerowane kociołki czy też manierki itd. Należy pamiętać także o najliczniejszej - jak można szacować - grupie artefaktów, czyli rzeczach wykonanych z drewna (ryc. 7). One jednak niemal nie zachowały się do chwili obecnej.

We wszystkich tych przypadkach można dostrzec - jak zauważają Carr i Mytum (2012b, s. 1) - to, że aspekty utylitarny i symboliczny w kontekstach obozowych zwykle nachodziły na siebie; były wręcz nierozerwalne. Wszystkie przedmioty, które

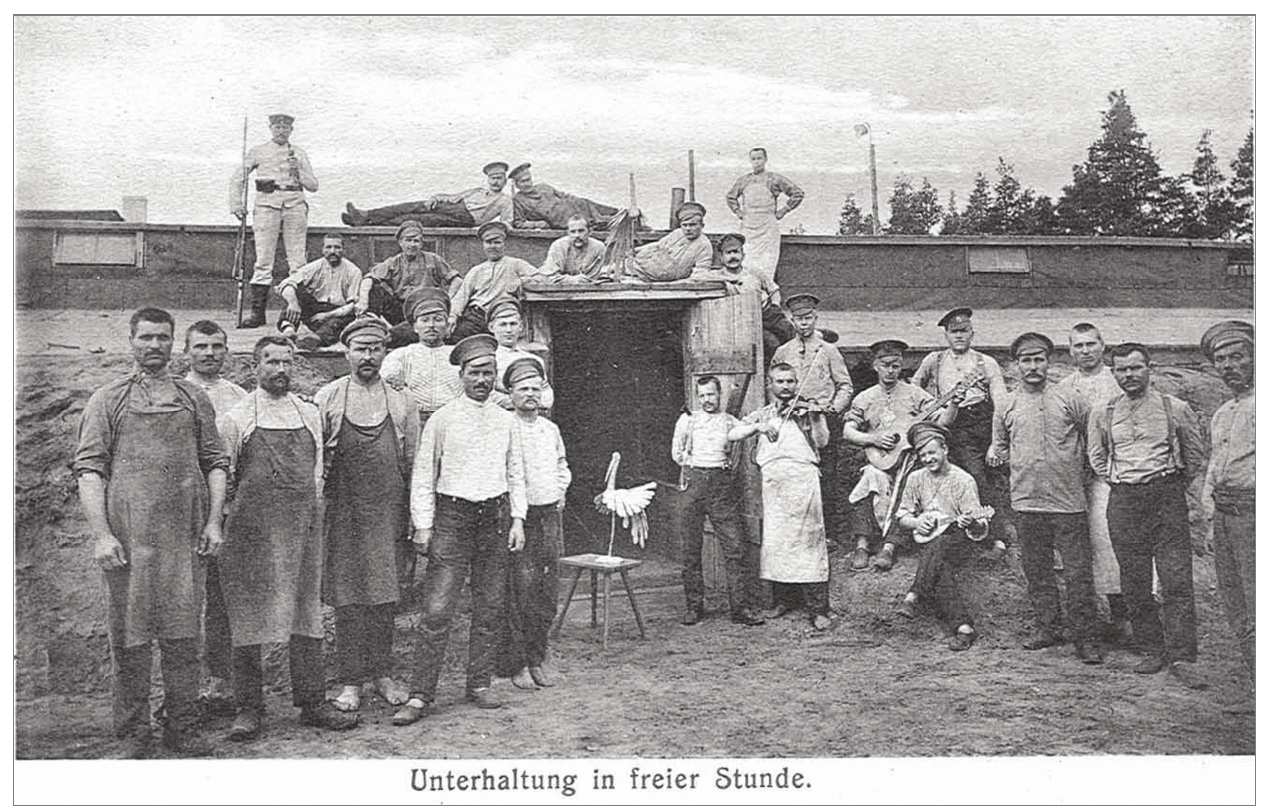

Ryc. 7. Niemiecka pocztówka propagandowa z obozu w Czersku ukazująca grupę rzemieślników przed warsztatem. To właśnie tacy obozowi specjaliści odpowiadali w większości przypadków za tworzenie bardziej złożonych przykładów sztuki okopowej. W centralnej części widokówki widać drewnianego ptaka (bociana?) - przykład sztuki okopowej (prywatne zbiory Dawida Kobiałki).

Fig. 7. A German propaganda postcard presenting a group of craftsmen at the Czersk camp. Thanks to such men we can now admire those more complex examples of trench art. In the centre, one can discern a wooden bird (stork?) - an example of trench art (private collection's Dawid Kobiałka). 
będą opisywane poniżej, łączy jeszcze jedna rzecz. Są one materialnymi wspomnieniami ludzkiej kreatywności za drutem kolczastym. Pozwalają one dostrzec jeńców nie tyle jako pasywne ofiary wyczekujące zakończenia konfliktu zbrojnego, wręcz odwrotnie, kultura materialna z Czerska będąca przykładem sztuki okopowej ukazuje żołnierzy jako mniej lub bardziej zdolnych rzemieślników walczących o przetrwanie. Artefakty te dotykają osobistych, czasem wręcz intymnych codziennych praktyk z życia obozowego. Takie rzeczy, idąc za ideą Matsa Burströma (2009), ukazują jakby ludzką twarz kultury materialnej związanej z konfliktami zbrojnymi; ludzi stojących za danymi artefaktami. Za tymi przedmiotami można dostrzec człowieka, jego osobiste uczucia, emocje, lęki, zmartwienia, wspomnienia - fragmentaryczność doświadczenia wojennego w postaci życia za drutem kolczastym, która została zmaterializowana $w$ danych artefaktach.

Zdaniem Carr i Mytum to właśnie owa wszechstronność, pomysłowość, owa jeniecka kreatywność jest jedną, można byłoby powiedzieć, z ram interpretacyjnych badań archeologicznych skupionych na analizowaniu materialnych reliktów obozowych. Jak zauważają Carr i Mytum (2012b, s. 3; thum. autora): „kreatywność w taki czy inny sposób była centralną formą przetrwania; była to konieczność - warunek wstępny - dla trwania i przetrwania czasu pojmania. Jest to jeden z powodów, dlaczego opowiadamy się za centralną rolą kreatywności w badaniach problematyki jenieckiej”. Wcześniej brytyjscy badacze czynią kluczową dla dalszego wywodu uwagę (Carr, Mytum, 2012b, s. 2; thum. autora):

Badania pokazują, że takiego czy innego rodzaju kreatywność była praktykowana prawie przez wszystkich jeńców wojennych (do różnego stopnia złożoności) i była terapeutycznym ujściem, które pozwalało im przetrwać emocjonalnie, psychicznie i, w niektórych przypadkach, fizyczne. Co więcej, ta kreatywność jest bogatym źródłem informacji, która pozwala badaczom spojrzeć w doświadczenia, postrzeganie i emocje z życia za drutem kolczastym.

Jeniecka sztuka okopowa ma specyficzny charakter (Carr, Mytum, 2012b; Saunders, 2010). Są to często przedmioty codziennego użytku, mające stanowić pomoc w przetrwaniu trudnego czasu niewoli (ryc. 8-9). Jak wiadomo z analizy dokumentów historycznych, w obozie panowały beznadziejne warunki: panoszyły się choroby zakaźne, jeńcy byli niedożywieni, brakowało niemalże wszystkiego itd. (por. Karpus, Rezmer, 1997; Marcinkiewicz, 2016; Wąsiewski, 2017). Stąd też klasycznymi, wręcz przejmującymi przykładami jenieckiej sztuki okopowej są różnego rodzaju naczynia wykonywane, przetwarzane z dostępnych materiałów. Na przykład rycina 8 prezentuje jeden $z$ takich wymownych, afektywnych materialnych manifestacji tego zjawiska. Jest to zardzewiały, zniszczony żelazny kubek, który służył do spożywania płynów (czaju, kawy, wody). Powstał on jednak z puszki po konserwie oraz fragmentu grubego, wytrzymałego drutu. Do takiej użytkowej sztuki okopowej należy zaliczyć również przedmiot z ryciny 9 . Przedstawia ona bowiem fragment jasnej 

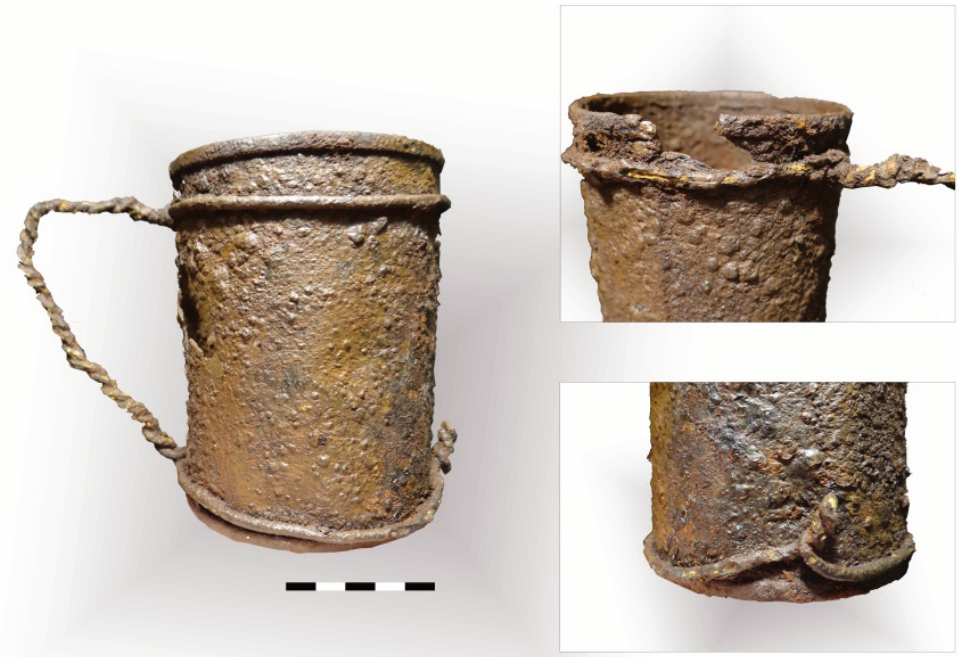

Ryc. 8. Metalowy kubek wykonany z puszki po konserwie, która została opleciona kawałkiem grubego, wytrzymałego drutu. Tego rodzaju sztuka okopowa jest bardzo charakterystyczną kategorią artefaktów $\mathrm{z}$ terenów obozów jenieckich (fot. Dawid Kobiałka).

Fig. 8. A metal mug made of a tin can which was coiled round by a fragment of an inflexible metal wire. Such category of trench art is a very characteristic material culture found at terrains of prisoner of war camps (photo by Dawid Kobiałka).

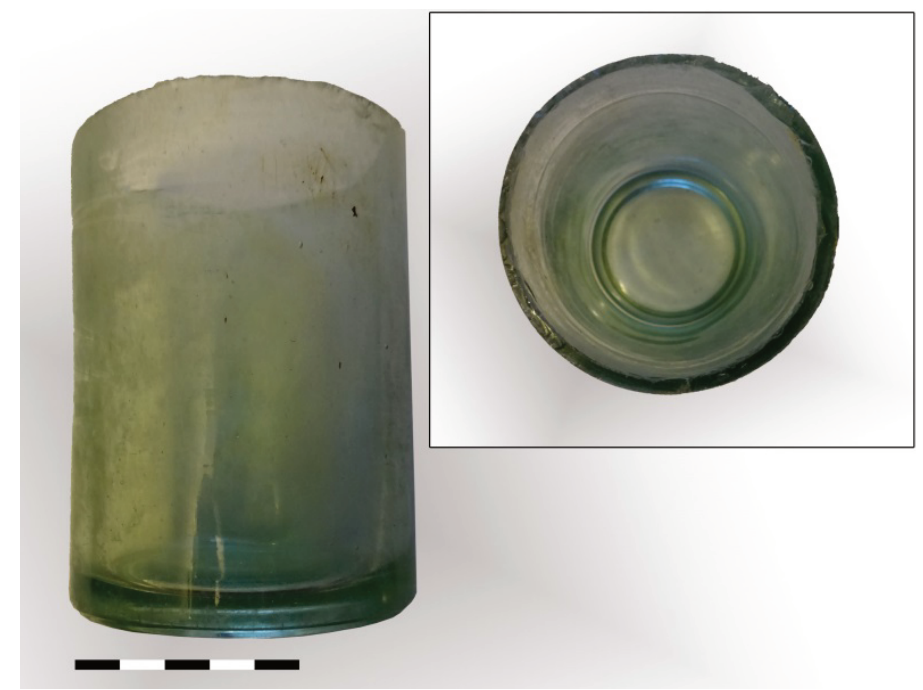

Ryc. 9. Przetwarzanie śmieci - nawet butelka po piwie została wykorzystana przez jeńca obozu w Czersku jako surowiec, który posłużył do wykonania szklanki. Z takich artefaktów jeńcy pili herbatę (tzw. czaj), kawę czy też wodę (fot. Dawid Kobiałka).

Fig. 9. Re-cycling trash - even a beer bottle was used by a prisoner of war at the Czersk camp as a materiel for making a glass. Such artefacts were used for drinking tea, coffee or water (photo by Dawid Kobiałka). 
szklanej butelki. Jest ona pojemnikiem po piwie. Jednak została odpowiednio obrobiona przez jeńca z Czerska. Szklana butelka została wykorzystana jako surowiec do wykonania szklanki, która była zapewne użytkowana przez jeńca w trakcie codziennego życia za drutem kolczastym w czerskim obozie. Materialne artefakty dają również wgląd w tragizm sytuacji jenieckiej, skoro ludzie musieli przetwarzać tego typu przedmioty na naczynia codziennego użytku.
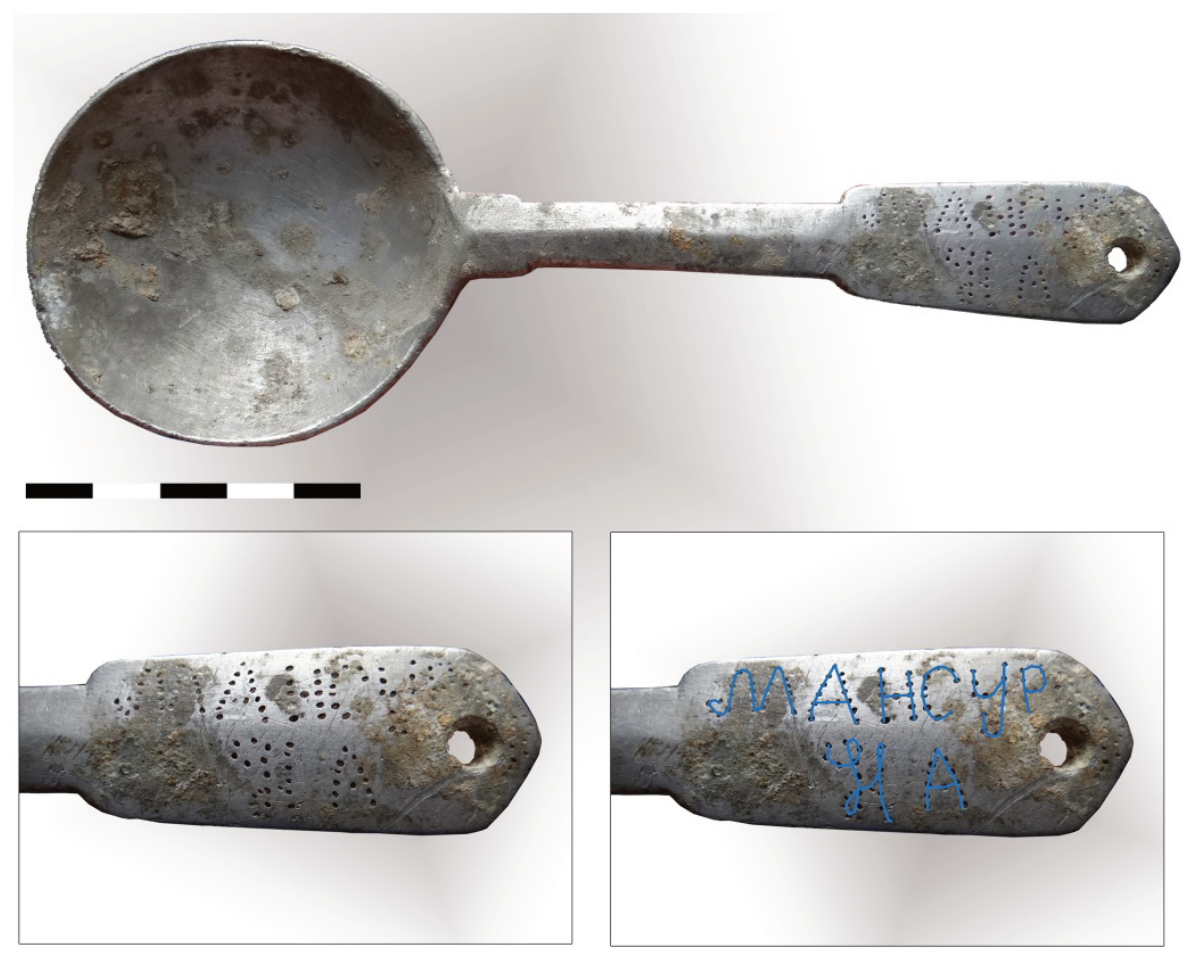

Ryc. 10. Łyżki musiały być bardzo cennymi artefaktami w obozie. Były one często personalizowane. W tym przypadku jeniec wykropkował swoje nazwisko MAHCYP(OB?) oraz inicjały imienia HA (fot. Dawid Kobiałka).

Fig. 10. Spoons were supposedly very important artefacts at the camp as they were often personalised. In this case, a prisoner of war engraved probably his surname MAHCYP(OB?) and first letters of his name HA (photo by Dawid Kobiałka).

Czasem niewielkie czynności utrwalone w materii pozwalają dany przedmiot zakwalifikować do zbioru sztuki okopowej (ryc. 10). Tak jest z aluminiową łyżką z ryciny 10 . Grafika przedstawia typową łyżkę, która była na wyposażeniu żołnierzy armii carskiej. Ma ona $17,3 \mathrm{~cm}$ długości oraz charakterystyczną szeroką przednią część. Tego rodzaju - wręcz banalne na pierwszy rzut oka artefakty - w kontekstach obozowych ulegały przewartościowaniu. Znanych jest wiele przypadków, gdzie 
sztućce, kociołki, manierki były grawerowane. Zwykle grawerunki sprowadzają się do prostych, krótkich inicjałów, czasem pełnych imion i nazwisk. Niemniej istnieje liczny zbiór manierek ze złożonymi, wielowątkowymi przedstawieniami i narracjami (por. Hubacz, 2017; Kobiałka, 2018a). Łyżka z Czerska ma na uchwycie wybite ostrym przedmiotem rzędy dziurek tworzących inskrypcję. Dziurki układają się w - jak się zdaje - słowo MAHCYP(OB?). Można tę inskrypcję interpretować jako nazwisko właściciela artefaktu. Litery HA znajdujące się poniżej to najprawdopodobniej jego inicjały imienia. Napisy tego rodzaju można postrzegać jako próbę oznaczenia swoich osobistych artefaktów. W trudnych warunkach obozowych nawet łyżka stawała się (bez)cenną rzeczą.

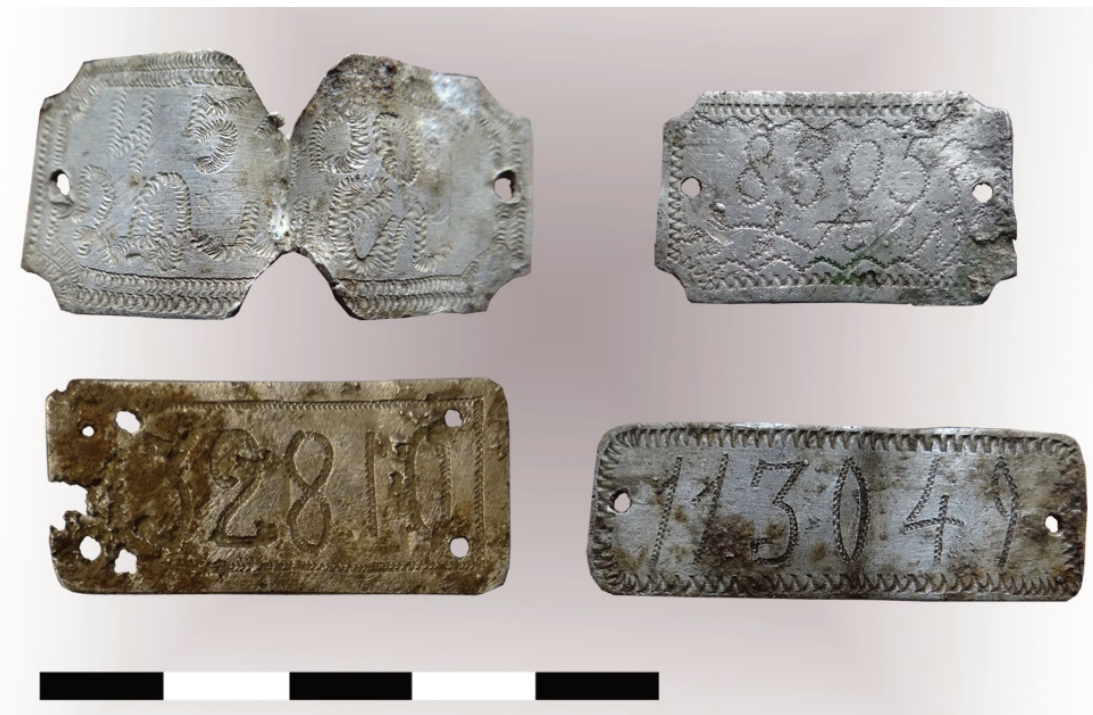

Ryc. 11. Plakietki z najprawdopodobniej numerami obozowymi. Każda tabliczka została wykonana w nieco inny sposób. Sugeruje to, że to sami jeńcy wykonywali tego rodzaju przedmioty (fot. Dawid Kobiałka).

Fig. 11. Plaques with probably camp numbers. Each plaque is made in a slightly different way. It may suggest that prisoners of war made such artefacts themselves (photo by Dawid Kobiałka).

Osobistymi artefaktami, użytkowanymi każdego dnia niewoli, były także numery obozowe (ryc. 11). Budowa oraz sprawne zarządzanie obozami i rzeszami ludzi wymagało szybkiego wypracowania odpowiednich procedur przez Niemcy. Rzecz jasna jednym z niezbędnych elementów tego procesu była dokumentacja przyjętych jeńców. Wraz z przekroczeniem bramy obozowej pojmany żołnierz, człowiek z imieniem i nazwiskiem, był redukowany do numeru obozowego; co też było skrupulatnie odnotowywane we właściwych rejestrach. Innymi słowy człowiek stawat 
się numerem. Jak wynika z analizy artefaktów z Czerska, nie istniał jeden wzór plakietki, na której administracja obozowa wybijała kolejne numery dla nowych jeńców. Rycina 11 przedstawia zbiór czterech aluminiowych plakietek z numerami, które można wstępnie interpretować jako numery obozowe. Jedna kwestia $\mathrm{w}$ tym przypadku zwraca szczególną uwagę: każda plakietka jest inna, ma nieco inne wymiary oraz sam numer został wykonany w nieco innej technice. Nie istniał zatem jeden schemat tworzenia obozowych plakietek $z$ numerami. Ta wysoce posunięta indywidualizacja danego artefaktu może świadczyć, że to sami jeńcy byli odpowiedzialni za wykonanie tych przedmiotów. Niewykluczone, że tabliczka była jednak obrabiana przez rzemieślnika obozowego w różnych technikach. Taka sugestia może doprowadzić do wniosku, że jeniec również po zagubieniu pierwotnej tabliczki był zobowiązany wykonać jej duplikat z identycznym numerem. Stąd też mogły się na nich pojawić dodatkowe dekoracyjne elementy w postaci grawerunku tworzącego ramkę dla danego numeru obozowego. Idąc tym tropem interpretacyjnym, można wręcz zakładać, że jeńcy traktowali te plakietki jako formy osobistej ozdoby noszonej na zniszczonym mundurze. Jak widać na rycinie 11 , artefakty tego rodzaju miały co najmniej dwie dziurki, które służyły do przyszycia/przymocowania ich do munduru na stałe. W końcu takie plakietki tworzą bardzo dystynktywną kategorię jenieckiej sztuki okopowej. Niektóre z tych przedmiotów mają nawet widoczne ślady naprawy.

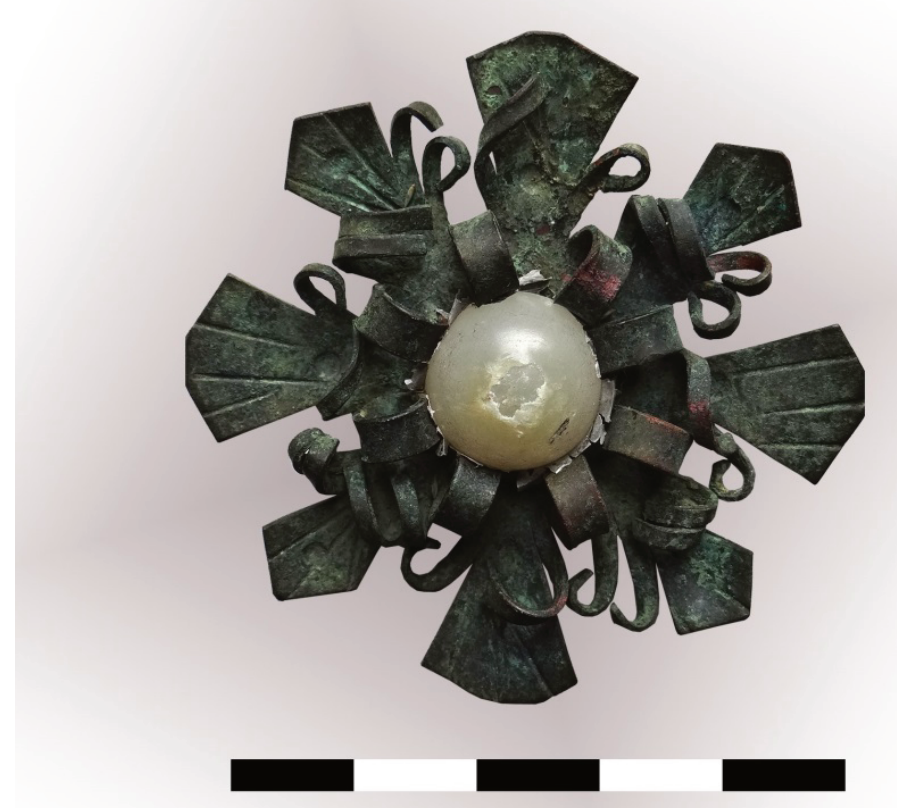

Ryc. 12. Pięknie wykonana mosiężna broszka mogąca stanowić obozowy środek wymienny (fot. Dawid Kobiałka).

Fig. 12. A beautiful, handmade brooch made probably for a barter (photo by Dawid Kobiałka). 
Osadzeni wytwarzali także przedmioty, które miały stanowić formę środka pieniężnego, materiału wymiennego (ryc. 12). Rycina 12 przedstawia starannie wykonaną mosiężną broszkę w kształcie rozwiniętego kwiatu. Rzeczy tego rodzaju mogły być także wymieniane z niemiecką administracją obozową na papierosy, jedzenie itd. Warto zwrócić w tym miejscu uwagę na dwa aspekty związane z produkcją tego przykładu sztuki okopowej. Po pierwsze nie można broszce odmówić wartości estetycznej - to staranna robota. Po drugie, aby wyprodukować tak złożone i trudne w obróbce ozdoby, jeńcy musieli mieć dostęp do specjalnych narzędzi. W pewnym sensie broszka potwierdza istnienie warsztatów, w których osadzeni mogli wytwarzać i przetwarzać kulturę materialną (por. ryc. 7).

Sztuka okopowa frontu zachodniego Wielkiej Wojny w wielu przypadkach upamiętniała czas konfliktu i jego społeczne, kulturowe oraz ekonomiczne reperkusje. Artefakty tego rodzaju miały bardzo często dodatkowe inskrypcje, mówiące na pamiątkę jakiego konkretnego wydarzenia zostały wykonane. Te informacje są

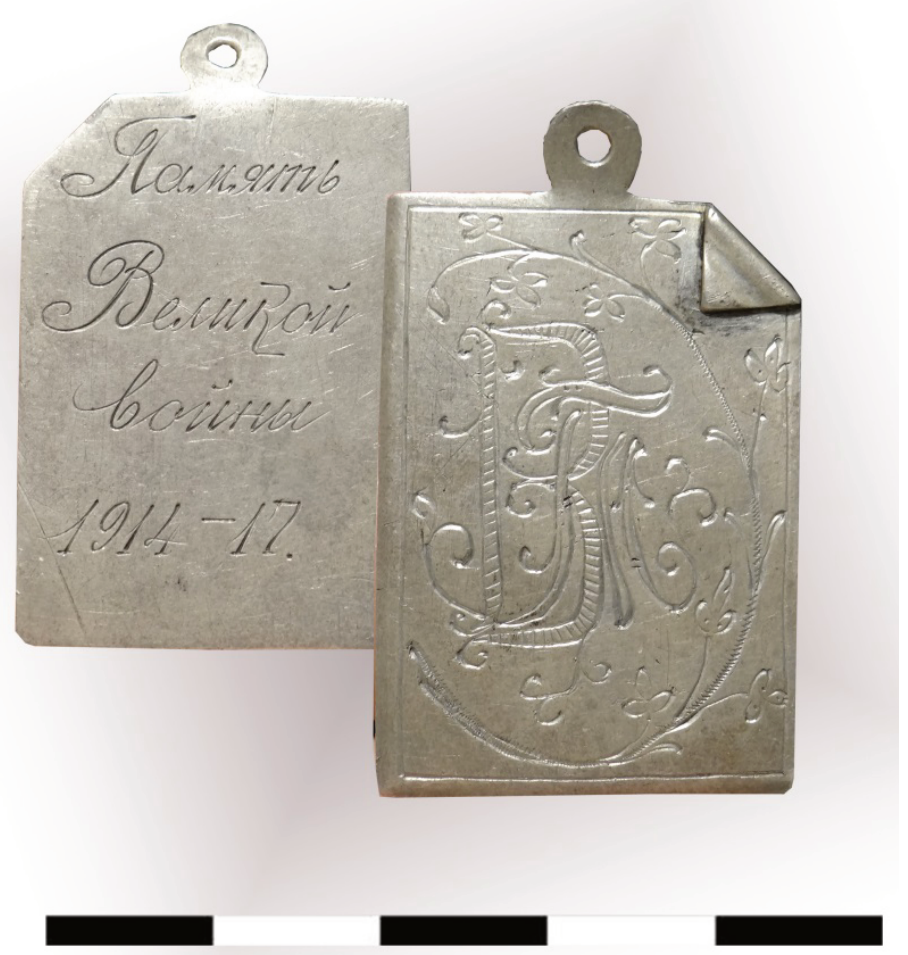

Ryc. 13. Srebrna zawieszka - materialna forma upamiętnienia Wielkiej Wojny 1914-1917 (fot. Dawid Kobiałka).

Fig. 13. A silver pendant - a material form of memorizing the Great War 1914-1917 (photo by Dawid Kobiałka). 
bezcenne, jeśli chodzi o datowanie danego przedmiotu i jego klasyfikację. Także z Czerska znane są artefakty, które można zaliczyć do tego zbioru (por. Kobiałka, 2018a). Jeden $z$ nich to niewielka srebrna plakietka, forma wisiorka, która została pokryta rytami (ryc. 13). Z jednej strony widać motywy florystyczne oraz litery WG wykonane w podobnej stylistyce. Zwykle pojedyncze litery na tego typu przedmiotach interpretuje się jako inicjały właściciela przedmiotu. Na rewersie ozdoby została wyryta inskrypcja cyrylicą, która mówi, że przedmiot jest pamiątką Wielkiej Wojny 1914-1917. Artefakty tego rodzaju są zarazem formą materialnej pamięci o ludzkich zdolnościach, emocjach, myślach, troskach. Starannie wykonana plakietka mogła być osobistym przedmiotem codziennie noszonym na szyi, upamiętnieniem czasu Wielkiej Wojny oraz, co jest tego konsekwencją, kolejnych lat spędzonych w Czersku.

Nie można zapomnieć, że sztuka okopowa związana z obozem w Czersku to nie tylko przedmioty odnalezione na terenie dawnego miejsca przetrzymywania żołnierzy. Należy pamiętać o tym, że jeńcy z Czerska byli tanią siłą roboczą. Lokalny rolnik, rzemieślnik, przedsiębiorca mógł za odpowiednią opłatą zatrudnić jeńców, którzy wykonywali różnego rodzaju prace (np. Wąsiewski, 2017). Jak się okazuje, $\mathrm{z}$ tym procesem wiązało się także wytwarzanie przedmiotów, które można zaliczyć do miana sztuki okopowej. Pojedyncze przedmioty oraz ich historie przetrwały do czasów współczesnych.

W trakcie badań terenowych w 2017 r. miałem okazję przeprowadzić rozmowę z Markiem Piechockim, który jest posiadaczem przykładowej sztuki okopowej z Czerska (por. także Ponikowski, 2014; Kobiałka, 2018b). Historia ta dobitnie pokazuje biograficzny wymiar sztuki okopowej; jak artefakty łączą w sobie różnych ludzi, miejsca, przeszłość i współczesność. W rodzinie wspomnianego rozmówcy zachowała się drewniana skrzynka z czasów I wojny światowej (ryc. 14). Artefakt ten został wykonany przez dwóch jeńców z obozu w Czersku, których wynajął do pracy w swoim warsztacie ceramicznym w Kościerzynie Augustyn Budziński, pradziadek Piechockiego. Jeńcy trafili do Budzińskiego pod koniec 1914 r. Pracowali m.in. przy wypale cegieł, produkcji kafli piecowych oraz elementów dekoracyjnych do początku 1918 r. Zapłatą za wykonane przez nich obowiązki było zabezpieczenie im podstawowych potrzeb, a więc znośnych warunków mieszkalnych oraz pożywienia. W międzyczasie, jak referował Piechocki w trakcie rozmowy, jeden $z$ jeńców miał dostać paczkę od rodziny. W pieczywie była ukryta wiadomość mówiąca o tym, że ma wracać do domu. W myśl zawartej informacji jeńcy postanowili uciec. Jako formę podziękowania za dobre traktowanie pradziadek Piechockiego miał dostać przedmiot z ryciny 14. To drewniana szkatułka stylizowana na kształt książki. Jest starannie zdobiona motywami florystycznymi. W górnej części szkatułki widnieje napis ХОЛМБ (Chołm), centralne miejsce zajmują słowa ПОМЯТЬ ВОИНЫ (Pamiątka wojny), najniżej zaś data 1914 18. Chołm, czyli nazwa miejscowości, może być miastem, w którym przynajmniej jeden z jeńców się urodził. Zawsze trze- 
ba być ostrożnym w interpretacji tego rodzaju napisów. Nie jest bowiem wykluczone, że słowo Chołm jest nazwą Chełm wykonaną z błędem (litera 'o' zamiast 'e'). Pamiatka wojny jest określeniem przeznaczenia artefaktu - była to materialna forma upamiętnienia konfliktu z lat 1914-1918.
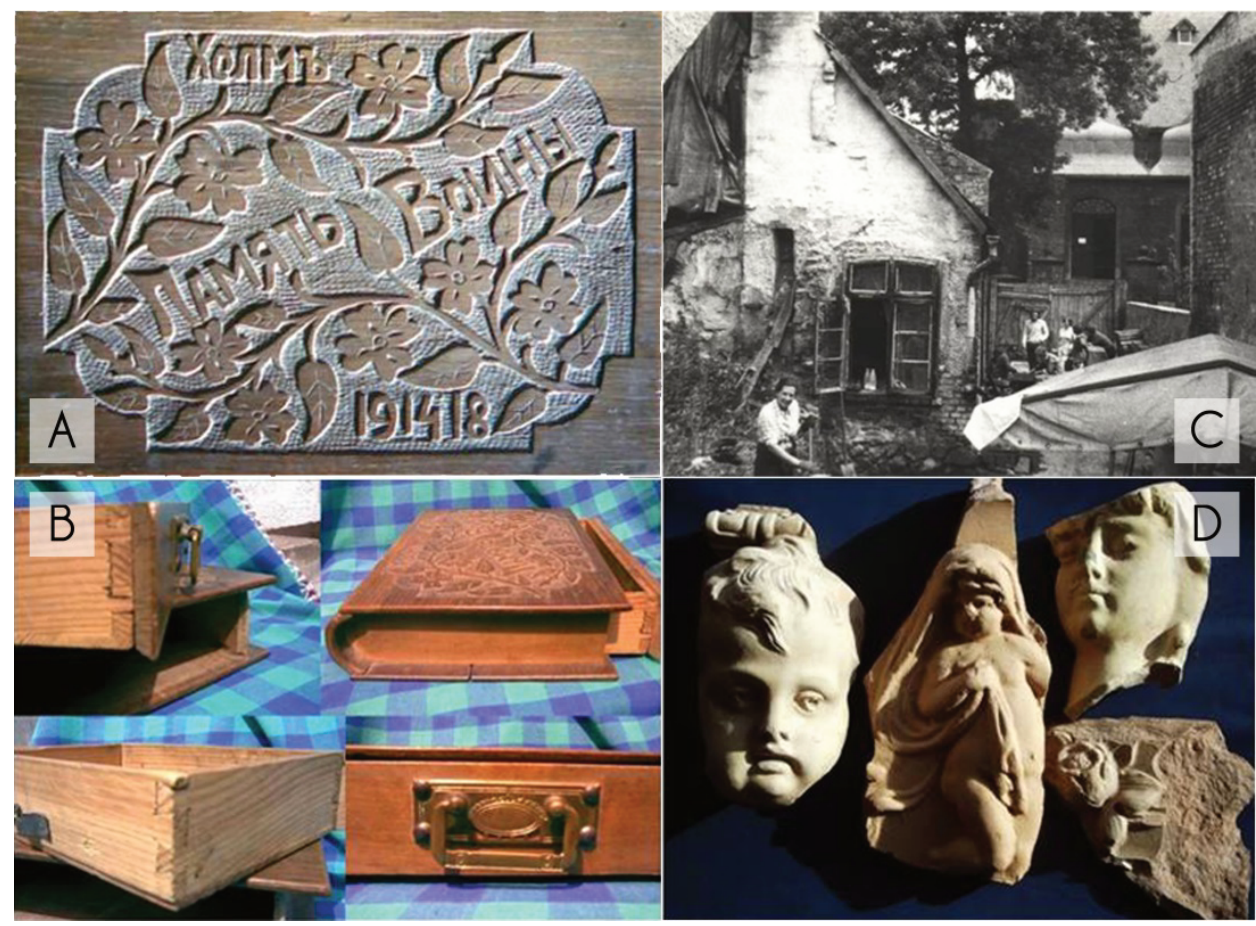

Ryc. 14. Biograficzny wymiar sztuki okopowej. A-B - drewniana szkatułka wykonana przez jeńców z obozu w Czersku (fot. Marek Piechocki); C - zdjęcie ukazujące warsztat ceramiczny Antoniego Budzińskiego, w którym pracowali jeńcy z obozu w Czersku (prywatne zbiory Marka Piechockiego); D - elementy dekoracyjne kafli, które miały zostać wykonane przez jeńców z obozu w Czersku (fot. Marek Piechocki).

Fig. 14. A biographical face of trench art. A-B - a wooden casket made by two Czersk prisoners of war (photo by Marek Piechocki); C - a photography documenting a clay workshop of Antoni Budziński in which the prisoners worked (private collection's Marek Piechocki); D - decorative elements of tiles which were made by the prisoners from the Czersk camp (private collection's Marek Piechocki).

Dzięki wywiadowi etnograficznemu udało się pozyskać informacje, które znacząco wzbogacają szerszy kontekst kulturowy sztuki okopowej z Czerska. Szkatułka pokazuje, jak splątane były w rzeczywistości losy rzeczy i jeńców z obozu w Czersku. W podobnym kontekście zadokumentowano cenne wspomnienia od Henryka Sikorskiego, mieszkańca Czerska. W trakcie rozmowy przeprowadzonej 17 marca 2017 r. opowiedział o dwóch historiach dotyczących obozu w Czersku, które usły- 
szał jako dziecko od swojej matki. Jedna z nich mówi o tym, że mieszkańcy Czerska mieli oficjalny zakaz zbliżania się do granic obozu. Jednak ten zakaz był łamany przede wszystkim przez miejscowe dzieci, które interesowały się tym, co się dzieje w okolicznych lasach. Ze wspomnień wynika, że dochodziło do interakcji między dziećmi a osadzonymi. Jeńcy dawali dzieciom różnego rodzaju zabawki wykonywane z drewna (por. ryc. 7) w zamian za pożywienie (kromkę chleba, ziemniaki itd.). Historia ta znajduje potwierdzenie w innych kontekstach historycznych, gdzie ogrodzenie z drutu kolczastego było strefą kontaktu i wymiany jenieckiej z lokalną społecznością (więcej w: Carr, Mytum, 2012a). Drewniane zabawki wykonane przez jeńców są także przykładem sztuki okopowej.

Opisywane $\mathrm{w}$ artykule artefakty mają wiele znaczeń, które ulegały zmianie na przestrzeni ostatniego wieku. Ważnym tego świadectwem jest historia drewnianej szkatułki. Piechocki przyznał w trakcie rozmowy, że artefakt to nie tylko pamiątka po pradziadku i jeńcach, których zatrudnił. Ten konkretny przedmiot to „relikwia”, rzecz o wymiarze wręcz duchowym (M. Piechocki, informacja ustna, 21.04.2017). Sztuka okopowa jest zatem materialnym medium łączącym żywych i umarłych, przeszłość i współczesność, wymiar spirytualny zapamiętany/utrwalony w materii.

\section{PODSUMOWANIE}

Celem artykułu było zwrócenie uwagi na znaczenie i wartość sztuki okopowej. Stanowi ona niezwykły wręcz przejaw jenieckiej pomysłowości, pragmatyczności za drutem kolczastym; jak każdy kawałek materii był wykorzystywany przez osadzonych; jak kategoria śmieć, odpad nie istniała w warunkach obozowych. Sztuka okopowa w całej swojej różnorodności i złożoności jest ucieleśnieniem tego, co jednostkowe i tego, co społeczne; materii i idei. To materialne medium między przeszłością a współczesnością, pomiędzy martwymi, którzy polegli na polu walki a żywymi; jest manifestacją relacji łączących ludzi i rzeczy (Saunders, 2000).

Wyjątkowa kolekcja sztuki okopowej z Czerska znajdująca się na Wystawie Przyrody Borów Tucholskich i Doliny Rzeki Wdy w Czarnej Wodzie jest pozbawiona pierwotnego kontekstu archeologicznego. Nieznane są relacje łączące te przedmioty z innymi artefaktami, dokładne miejsca ich zdeponowania itd. To rzeczy pozyskane przez zespół regionalistów działających legalnie w ramach Elbląskiego Stowarzyszenia Eksploracyjnego Ilfing. Eksponaty są wynikiem prac grupy miłośników lokalnej historii. To właśnie tacy ludzie dostrzegli jako pierwsi walory historyczne materialnych pozostałości obozowych, dziedzictwa wielkowojennego w lasach pod Czerskiem.

Archeolodzy zbywali przez długie dekady pozostałości z wojen światowych jako rzeczy, stanowiska pozbawione wartości. Dopiero na przestrzeni ostatniej dekady ulega to powolnemu przewartościowaniu. $\mathrm{W}$ ten sposób polska nauka zdaje się, że 
zmierza ścieżką archeologii belgijskiej (więcej w: Saunders, 2010), gdzie również znaczenie dziedzictwa pierwszowojennego zostało najpierw dostrzeżone przez regionalistów, lokalnych poszukiwaczy skarbów. Dopiero jakiś czas później rzeczy z czasów I i II wojny światowej stały się przedmiotem archeologicznych badań terenowych. Zaowocowało to narodzinami osobnych gałęzi badań archeologicznych: archeologii pierwszej wojny światowej (Saunders, 2010) czy też archeologii drugiej wojny światowej (Moshenska, 2013) lub też, mówiąc najogólniej, archeologii wspótczesnych konfliktów zbrojnych. W tym kontekście można lokować archeologiczne badania przestrzeni obozowych i jenieckiej kultury materialnej.

Należy na koniec podkreślić recyklingowa naturę sztuki okopowej. Jej potwierdzeniem są także artefakty z Czerska. Sztuka okopowa polegała na wytwarzaniu, przerabianiu tego, co żołnierz, jeniec, cywil miał pod ręką i co drogą wymiany, kradzieży itd. mógł nabyć. Na przykład wykonaną z metalu broszkę można było wymienić na papierosa czy też pożywienie. Również obecnie sztuka okopowa z Czerska podlega kolejnemu recyklingowi. Tym razem dotyczy on raczej jej strony niematerialnej. Przedmioty, które były kiedyś rzeczami codziennego użytku, formą upamiętniania i pamiątek, dzisiaj po stu latach traktowane są jako wartościowe dziedzictwo wielkowojenne. Są to także memorabilia, przedmioty zbierane, sprzedawane przez niektórych poszukiwaczy skarbów. Artefakty tego typu zdobią zbiory, jak można zakładać całkiem licznych prywatnych kolekcji, które w większości przypadków nigdy nie zostaną opracowane naukowo. W końcu wiek później te materialne relikty są postrzegane coraz częściej jako wartościowe dziedzictwo o znaczeniu historycznym, kulturowym i archeologicznym (Kobiałka, 2018a, 2018b).

Sztuka okopowa z Czerska jest dziedzictwem archeologicznym. Jednym z wyników badań w ramach projektu pt. Między pamięcia a zapomnieniem: archeologia a XX-wieczne dziedzictwo militarne na terenach zalesionych było wykonanie Karty Ewidencji Stanowiska Archeologicznego dla obozu. Obóz w Czersku to po prostu stanowisko archeologiczne. Podobnie artefakty obozowe, w tym też przykłady sztuki okopowej nie są już śmieciami: zniszczonymi, zardzewiałymi, potłuczonymi fragmentami przedmiotów z lat 1914-1919.

W ramach podsumowania warto postawić postulat badawczy na najbliższą przyszłość. Polscy archeolodzy muszą podjąć prace wykopaliskowe na terenach obozów pierwszowojennych. Jednym z ich wyników będzie zapewne pozyskanie przedmiotów in situ, w swoim pierwotnym kontekście archeologicznym, co pozwoli zdobyć wiele nowych, cennych informacji. Zapewne udałoby się odkryć metodami stricte archeologicznymi kolejne przykłady sztuki okopowej. Jednymi z nielicznych przedmiotów odkrytych w trakcie rekonesansów terenowych w 2017 i 2018 r. na obszarze obozu w Czersku, które można włączyć do kategorii sztuki okopowej, były zardzewiałe, zniszczone dwa niewielkie kociołki wykonane z puszek po konserwach i kawałków drutu (ryc. 15). 


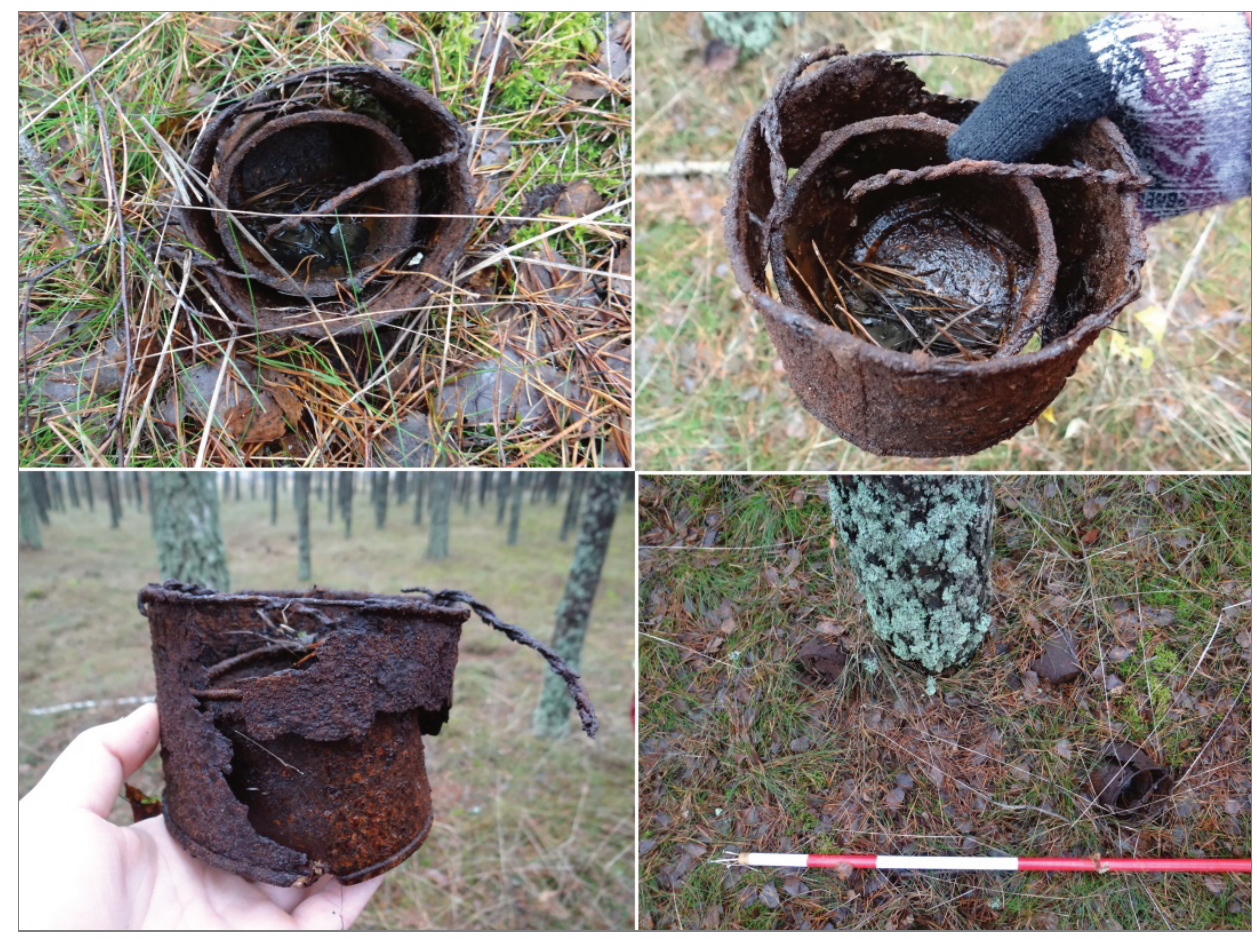

Ryc. 15. Puszki po konserwach zostały przerobione na kociołki, w których gotowali jeńcy z Czerska. Są to jedynie przykłady sztuki okopowej, które udało się zadokumentować w trakcie rekonesansów terenowych (fot. Dawid Kobiałka).

Fig. 15. Tin cans were re-used as kettles in which prisoners cooked food and liquids. These are the only examples of trench art documented during the field research (photo by Dawid Kobiałka).

\section{PODZIĘKOWANIA}

Dziękuję Piotrowi Szulcowi, Mikołajowi Kostyrce, Kornelii Kajdzie, Markowi Piechockiemu, Alicji Marcinkiewicz, Henrykowi Sikorskiemu, Łukaszowi Józefowi Hubaczowi, Robertowi Ryndziewiczowi, Filipowi Wałdochowi oraz Akramowi Abo Alfozie, którzy, w różny sposób, pomogli mi w trakcie badań. Anna Kobiałka, jak zawsze, opracowała graficznie ryciny do tekstu.

Badania są częścią projektu finansowanego ze środków Narodowego Centrum Nauki przyznanych na podstawie decyzji numer DEC-2016/20/S/HS3/00001.

\section{BIBLIOGRAFIA}

Bączyk, J., Kaczmarek, M., Usurski, M.

2018 Obóz jeniecki w Pile 1914-1919: wspomnienia jeńców. Piła: Muzeum Stanisława Staszica w Pile. 
Buchli, V., Lucas, G. (red.)

2001 Archaeologies of the Contemporary Past. London - New York: Routledge.

Burström, M.

2009 Looking into the Recent Past: Extending and Exploring the Field of Archaeology. Current Swedish Archaeology, 15-16, 21-36.

Bystryk, R.

2016 Lager Czersk 1914-1919. Zeszyty Czerskie, 4, 23-41.

Czarnowicz, M., Ochał-Czarnowicz, A., Kołodziejczyk, P.

2016 Ślady Wielkiej Wojny w Karpatach. Badania i dokumentacja elementów umocnień w rejonie Jaślisk i Moszczańca w latach 2015-2016. Wiadomości Konserwatorskie, 46, $110-118$.

Carr, G., Mytum, H. (red.)

2012a Cultural Heritage and Prisoners of War: Creativity behind Barbed Wire. New York: Routledge.

Carr, C., Mytum, H.

2012b The Importance of Creativity behind Barbed Wire. Setting a Research Agenda. W: G. Carr, H. Mytum (red.), Cultural Heritage and Prisoners of War: Creativity behind Barbed Wire (s. 1-15). New York: Routledge.

Cesarani, D., Kushner, T. (red.)

1993 The Internment of Aliens in Twentieth Century Britain. London: Frank Cass.

Cresswell, Y.

2005 Behind the Wire: The Material Culture of Civilian Internment on the Isle of Man in the First World War. W: R. Dove (red.), 'Totally Un-English'? Britain's Internment of 'Enemy Aliens' in Two World Wars (s. 45-61). New York: Rodopi.

Dąbrowski, J.

2015 Wielka Wojna 1914-1918. Oświęcim: Napoleon V.

Hubacz, Ł. J.

2017 Manierki jeńców wojennych 1914-1918 na tle manierek państw zaborczych/Canteens of Prisoners of War 1914-1918 Compared with the Ones of Occupants. Mińsk Mazowiecki: Muzeum Ziemi Mińskiej.

Karczewski, M., Karczewska, M.

2014 Archeologia I wojny światowej na giżyckim odcinku frontu wschodniego. W: R. Kempa (red.), Wielka Wojna na Mazurach 1914-1915. Studia z dziejów frontu wschodniego I wojny światowej (s. 393-403). Giżycko: Towarzystwo Miłośników Twierdzy Boyen.

Karski, K., Różycki, S., Schwarz, A.

2017 Memories of Recent Past. Objectives and Results of Non-invasive Archaeological Research Project at KL Plaszow Memorial Site. Analecta Archaeologica Ressoviensia, 12, 221-246.

Karpus, Z., Rezmer, W.

1997 Tuchola. Obóz jeńców i internowanych 1914-1923 (t. 1, cz. 1). Toruń: Wydawnictwo UMK.

Karpus, Z., Rezmer, W.

1998 Tuchola. Obóz jeńców i internowanych 1914-1923 (t. 1, cz. 2). Choroby zakaźne $i$ walka z nimi (1920-1922). Toruń: Wydawnictwo UMK.

Karpus, Z., Wiszka, E., Sribniak, I.

2007 Tuchola. Obóz jeńców i internowanych 1914-1923 (t. 1, cz. 3). Warunki życia jeńców i internowanych. Toruń: Wydawnictwo UMK. 
Kobiałka, D.

2017 Biografia zapisana na manierce. Archeologia Żywa, 2(64), 60-63.

Kobiałka, D.

2018a 100 Years Later: The Great War, Memory, Woodlands and a prisoner of war Camp in Czersk, Poland, as Dark Heritage. Antiquity, 92(363), 772-787.

Kobiałka, D.

2018b Sztuka okopowa: doświadczenia i wspomnienia wojenne utrwalone w materii. Archeologia Żywa, 2(68), 76-80.

Kobiałka, D., Kostyrko, M., Kajda, K.

2016 Archeologia poza archaīos. Przykład obozu jeńców wojennych i internowanych w Tucholi (woj. kujawsko-pomorskie). Folia Praehistorica Posnaniensia, 21, 177-200.

Kobiałka, D., Kostyrko, M., Kajda, K.

2017a The Great War and its Landscapes between Memory and Oblivion: The Case of Prisoners of War Camps in Tuchola and Czersk, Poland. International Journal of Historical Archaeology, 21(1), 134-151.

Kobiałka, D., Kostyrko, M., Kajda, K.

2017b Inconspicuous and Forgotten Material Memories of the First World War: The Case of a POW Camp in Czersk, Poland. W: A. Zalewska, J. Scott, G. Kiarszys (red.), The Materiality of Troubled Pasts. Archaeologies of Conflicts and Wars (s. 23-39). Warszawa Szczecin: Department of Archaeology, Szczecin University, Roadside History Lessons Foundation.

Kola, A.

2000 Betzec: the Nazi Camp for Jews in the Light of Archaeological Sources. Excavations 1997-1999. Warsaw: Council of Protection of Memory of Combatant Martyrdom.

Kostyrko, M.

2018 Biografia przesztych krajobrazów wobec danych teledetekcyjnych [Niepublikowana dysertacja doktorska. Poznań: Instytut Archeologii UAM w Poznaniu].

Majorek, M., Grupa, M.

2015 Auschwitz II Birkenau. Wyniki badań archeologicznych infrastruktury obozowej zwierciadłem życia więźniów. W: O. Ławrynowicz, J. Żelazko (red.), Archeologia totalitaryzmu. Ślady represji 1939-1956 (s. 169-184). Łódź: Instytut Archeologii Uniwersytetu Łódzkiego, Instytut Pamięci Narodowej Komisja Ścigania Zbrodni przeciwko Narodowi Polskiemu Oddział w Łodzi.

Marcinkiewicz, A.

2016 Śmiertelność jeńców wojennych w latach 1914-1918 na terenie Prus Wschodnich. Koto Historii, 19, 115-125.

Minta-Tworzowska, D.

1994 Klasyfikacja $w$ archeologii jako sposób wyrażania wyników badań, hipotez i teorii archeologicznych. Poznań: Wydawnictwo Naukowe UAM.

Moshenska, G., Myers, A.

2011 An Introduction to Archaeologies of Internment. W: A. Myers, G. Moshenska (red.), Archaeologies of internment (s. 1-19). New York: Springer.

Myers, A., Moshenska, G. (red.)

2011 Archaeologies of Internment. New York: Springer.

Myers, A., Moshenska, G.

2014 Confinement and Detention in Political and Social Archaeology. W: C. Smith (red.), Encyclopedia of Global Archaeology (s. 1623-1633). London - New York: Springer. 
Mytum, H.

2014 Internment and Prisoners of War in Historical Archaeology. W: C. Smith (red.), Encyclopedia of Global Archaeology (s. 4006-4011). London - New York: Springer.

Mytum, H., Carr, G. (red.)

2013a Prisoners of War: Archaeology, Memory, and Heritage of 19th-and 20th-Century Mass Internment. New York: Springer.

Mytum, H., Carr, G.

2013b Prisoner of War Archaeology. W: H. Mytum, G. Carr (red.), Prisoners of War: Archaeology, Memory, and Heritage of 19th-and 20th-century Mass Internment (s. 1-19). New York: Springer.

Nagornaja, O., Mankoff, J.

2009 United by Barbed Wire: Russian POWs in Germany, National Stereotypes, and International Relations, 1914-22. Kritika: Explorations in Russian and Eurasian History, 10(3), 475-498.

Olivier, L.

2011 The Dark Abyss of Time: Archaeology and Memory. Lanham, MD: AltaMira Press.

Olsen, B., Witmore, C.

2014 Sværholt: Recovered Memories from a POW Camp in the far North. W: B. Olsen, P. Pétursdóttir (red.), Ruin Memories: Materialities, Aesthetics and the Archaeology of the Recent Past (s. 162-190). London - New York, NY: Routledge.

Pawlicka-Nowak, $\mathrm{t}$.

2015 Badania archeologiczne na terenie byłego niemieckiego ośrodka zagłady w Chełmnie nad Nerem. W: O. Ławrynowicz, J. Żelazko (red.), Archeologia totalitaryzmu. Ślady represji 1939-1956 (s. 135-168). Łódź: Instytut Archeologii Uniwersytetu Łódzkiego, Instytut Pamięci Narodowej Komisja Ścigania Zbrodni przeciwko Narodowi Polskiemu Oddział w Łodzi.

Ponikowski, M.

2014 Tajemnica drewnianej szkatułki i obóz jeniecki w Czersku. Nasza Historia, 10(11), $14-17$.

Pope-Hennessy, U. B.

1920 Map of the Main Prison Camps in Germany and Austria. London: Nisbet \& Co. Ltd.

Rola, J., Stasiak, M., Kwiatkowska, M.

2015 Badania sondażowe na terenie obozu jenieckiego z I wojny światowej w Pile. Wielkopolskie Sprawozdania Archeologiczne, 16, 253-258.

Saunders, N.

2000 Bodies of Metal, Shells of Memory: 'Trench Art', and the Great War Re-cycled. Journal of Material Culture, 5, 43-67.

Saunders, N.

2003 Trench Art: Materialities and Memories of War. Oxford: Berg.

Saunders, N.

2004 Material Culture and Conflict: the Great War, 1914-2003. W: N. Saunders (red.), Matters of conflict. Material culture, memory and the First World War (s. 1-25). LondonNew York, NY: Routledge.

Saunders, N.

2010 Killing Time: Archaeology and the First World War. Stroud: Sutton.

Smagliński, F.

1993 Utuliła ich pomorska ziemia. Echo Czerska. Miesięcznik Komitetu Obywatelskiego, 11(43), 1 . 
Sturdy Colls, C.

2015 Holocaust Archaeologies: Approaches and Future Directions. New York: Springer.

Tomczyszyn, P.

2004 A Material Link between War and Peace: First World War Silk Postcards. W: N. Saunders (red.), Matters of Conflict: Material Culture, Memory and the First World War (s. 123-133). London: Routledge.

Usurski, M.

2018 Obóz jeniecki w Pile 1914-1919: wystawa. Piła: Muzeum Stanisława Staszica w Pile.

Wąsiewski, J.

2017 Księga pamięci. Jeńcy wojenni zmarli podczas Wielkiej Wojny 1914-1918 w Kriegsge-

Wężyk, P. (red.)

fangenenlager Czersk. Gdynia - Czersk - Czarna Woda: Józef Wąsiewski.

2014 Podręcznik dla uczestników szkoleń z wykorzystaniem produktów LiDAR. Warszawa: Główny Urząd Geodezji i Kartografii.

Wroniecki, P., Jaworski, M., Kostyrko, M.

2015 Exploring Free LiDAR Derivatives. A User's Perspective on the Potential of Readily Available Resources in Poland. Archaeologia Polona, 53, 611-616.

Zalewska, A.

2016 The 'Gas-scape' on the Eastern Front, Poland (1914-2014). Exploring the Material and Digital Landscapes and Remembering those 'Twice-killed'. W: B. Stichelbaut, D. Cowley (red.), Conflict Landscapes and Archaeology from Above (s. 147-165). Farnahm, Burlington: Routledge.

Zalewska, A., Cyngot, D.

2017 Problem zanikania pamięci o miejscach spoczynku żołnierzy poległych w walkach nad Rawką i Bzurą w latach 1914-1915. Acta Universitatis Lodziensis. Folia Archaeologica, $32,131-173$.

\section{Źródła elektroniczne}

Gilead, I., Haimi, Y., Mazurek, W.

2010 Excavating Nazi Extermination Centres. PresentPasts, 1, 1-12. Pobrano z: http://www. presentpasts.info/article/view/pp.12/2

http://www.auschwitz.org/galeria/sztuka-obozowa-i-poobozowa/

https://religionresearch.org/closer/2016/12/30/turning-weapons-of-war-into-art-syrian-artist-akram-aboalfoz/

\section{CREATIVITY BEHIND BARBED WIRE: ARCHAEOLOGY AND TRENCH ART FROM A PRISONER OF WAR CAMP IN CZERSK (POMERANIAN PROVINCE)}

\section{S u m m a r y}

The starting point for this article was a growing interest of archaeologists in material heritage of the Great War. Whereas the archaeological research concerning the Western Front of the Great War has been carrying out for the last two decades, archaeological research on the Eastern Front of 
the First World War has just started a few years ago. The interest in an archaeological value of such material heritage constitutes the research framework.

At first sight, the Eastern Front is characterized by kilometers of trenches, thousands of craters left by explosive materials, hundreds of war cemeteries, etc. However, part of that heritage are prisoner of war camps built by the Germans to imprison the captured soldiers. One of them was located in the forests around Czersk (Pomeranian province, Poland) (Kriegsgefangenenlager Czersk). The site was treated as if it were an archaeological site. Accordingly, this article discusses the results of archaeological and anthropological research concerning material remains of a prisoner of war camp in Czersk. In the first part, I sketch a broader historical context related to building and functioning of the camp in forests around Czersk between 1914-1919.

After that, the role and meaning of archaeological research on such type of archaeological sites are presented. Material remains of such camps create very distinctive and characteristic assemblages of objects. The materiel offers insight into class and gender relations at camps, camp landscapes, what and who was used and re-used by prisoners, up to and including, day-to-day life behind barbed wire. It is argued that such material culture enriches our understanding of the recent past. It is the subject of a new branch of archaeological research called archaeologies of internment or prisoners of war archaeology.

The third part introduces and discusses a very unique category of material heritage left by prisoners of war - trench art. Following the studies of Nicholas Saunders (2010), I discuss what trench art is and present closer a typology of trench art proposed by the British archaeologist.

The last part of this paper is a case study where an assemblage of objects classified as trench art that was found at the camp is described and interpreted. Among the artefacts there are tin cans used as mugs, beer bottles changed into glasses, plaques with camp numbers, different kinds of ornaments made by the Czersk prisoners (pendants, brooches, etc.), up to and including a wooden casket with floristic engravings.

All in all, this text aims at highlighting the value of such prisoners and camp's heritage. Such material culture is a material memory of extraordinary prisoners' creativity behind barbed wire. It makes one aware of how every piece of trash, rubbish was re-cycled during day-to-day life behind barbed wire. 